\title{
The origin of 'tauw', an enigmatic building stone of the Mergelland: a case study of the Hesbaye region, southwest of Maastricht (Belgium)*
}

\author{
M. Dusar ${ }^{1,}{ }^{*}$, R. Dreesen ${ }^{2}$, L. Indeherberge ${ }^{3}$, E. Defour ${ }^{4}$ \& R. Meuris ${ }^{5}$
}

1 Royal Belgian Institute of Natural Sciences, Geological Survey of Belgium, Jennerstraat 13, B-1000 Brussels, Belgium.

2 VIT0, Flemish Institute of Technogical Research, Boeretang 200, B-2400 Mol, Belgium.

3 Werkgroep Krijt \& Vuursteeneluvium, Reuvoortweg 63, B-3520 Zonhoven, Belgium.

4 Werkgroep Krijt \& Vuursteeneluvium, Opperstraat 9, B-3550 Heusden-Zolder, Belgium.

5 Werkgroep Krijt \& Vuursteeneluvium, Lijsterstraat 11, B-2580 Beerzel, Belgium.

* Corresponding author. Email: michiel.dusar@natuurwetenschappen.be.

Manuscript received: October 2010, accepted: April 2011

\begin{abstract}
The origin of a peculiar type of silicified limestone with nodular flints used in parish churches at Sluizen and Vreren, south of Tongeren (province of Limburg, Belgium), has now been elucidated by the discovery of the same rock type in its natural setting, namely the silicified top of the Cretaceous which underlies Clay-with-flints ('flint eluvium') and Oligocene sands in a disused quarry at Elst, municipality of Riemst (Limburg, Belgium). Co-operation between professional geologists and amateur palaeontologists has allowed to characterise this rock type, here referred to as 'Elst tauw', both petrographically and palaeontologically. The rich echinoid fauna has also been assessed, on the basis of a comparison with assemblages from the Clay-with-flints at Halembaye (Haccourt/Lixhe, province of Liège, Belgium) and at Zichen-Eben Emael in the Hesbaye region. P.J. Felder's ecozones, based on bioclast assemblages, substantiated by analyses of petrographical biofacies features of the original calcarenite, has allowed lithostratigraphic correlation of the 'Elst tauw' with the 'Roosburg block', which is a variety of 'Maastricht stone'. Both methods indicate that the 'Elst tauw' developed in beds that can be assigned to the condensed Valkenburg-Schiepersberg interval of the lower Maastricht Formation. Petrographical analysis has shown the 'Elst tauw' to be quite distinctive; in addition, its natural occurrence at the Elst quarry matches the building stone records in rock type. The latter stem from the same small area, situated southwest of Maastricht. The major steps in its diagenetic history could be reconstructed, starting with pervasive pyritisation of the calcareous allochems, followed by silicification of the grains and pore spaces (different silica cements that became partially recrystallised), completed by oxidation of pyrite with transformation into limonite and, finally, dissolution of the non-pyritised or partially pyritised skeletal allochems creating a mouldic porosity. Silicification probably was achieved prior to the Oligocene. This particular mode of formation has generated a discussion on the proper use of the vernacular term 'tauw', a term used in a different sense by the industry, stratigraphers and students of building stones.
\end{abstract}

Keywords: Cretaceous, Limburg, Maastricht limestone, palaeontology, petrography, silicification

\section{Introduction - 'tauw' as a building stone}

The provinces of Limburg in Belgium and the Netherlands have a rich architectural heritage built in stone, the most typical of which are rocks of Cretaceous age. These outcrop in the so-called 'Mergelland' in the southern part of these provinces and adjoining portions of the province of Liège (Belgium) and the
Aachen city area in Germany (Dusar \& Dreesen, 2007). The most famous building stone is without doubt the Maastricht stone ('Maastrichtersteen'), an extremely porous and soft, yet durable, creamy yellow, very pure calcarenitic limestone, extracted from hundreds of underground quarries, locally referred to as 'mergelgrotten' (W.M. Felder \& Bosch, 2000; Dubelaar et al., 2006). However, within the outcrop or shallow subcrop zone of

* In: Jagt, J.W.M., Jagt-Yazykova, E.A. \& Schins, W.J.H. (eds): A tribute to the late Felder brothers - pioneers of Limburg geology and prehistoric archaeology. 
southern Limburg, a wider range of Cretaceous rock types has been used as building stone. Their use was either widespread, e.g. flint (vuursteen, silex, Feuerstein; more generally known as chert) or local and predominant in the area of origin (such as the 'Kunradersteen'), while other stone types were more rarely used or elusive in their identification. The latter category encompasses particular stone types that are silicified, with varying silica and carbonate contents and either micro- or macroporous, and often fossiliferous. These are locally known as 'tauw' or 'heerd', rock types more solid and durable but also more difficult to handle than the classic Maastricht stone.

'Tauw' has been used as a building stone throughout the Mergelland, although rarely in great quantities, and mainly for sculpturing purposes or in places exposed to greater pressures or to mechanical wear. Because of their strength and resistance to weathering they were among the first building stones to be used, already during Roman times (Keuller, 1912). Their durability allowed them to be recycled throughout successive building phases. Besides regular formats, large blocks are found in churches, whereas smaller stones and irregular formats were rather used in vernacular architecture. This, 'tauw' as a building stone is quite variable between places of occurrence. Apparently, the only common characteristic is a diagenetic silicification which differs from syngenetic flint. Not much is known about its stratigraphic origin, geological history, provenance, petrography or mechanical properties. Characterisation requires a link to the natural environment from which the building stone was extracted. As 'tauw' occurrences do not share many common characteristic features, it is advisable to define each type separately.

One peculiar type of 'tauw', first mentioned but not described in detail by Dusar et al. (2009), was found exclusively in the
St Servatius church at Sluizen and the St Medardus church at Vreren. Both villages are located in the River Jeker valley, south of Tongeren and southwest of Maastricht (Fig. 1). These churches are romanesque, heavily restored but they clearly include recycled building stones. Within the patchwork of Maastricht stone, flint, silicified chalk (from the Clay-withflints) and other regional stone types, some large, roughly chiseled, quadratic to rectangular stones stand out. These display a yellowish colour similar to that of Maastricht stone (when fresh), and a greenish grey patina with rusty brown patches (when weathered). Smooth flint tubes smaller than $10 \mathrm{~cm}$ in diameter are incorporated in their matrix, as a result of a pervasive secondary silicification. Nevertheless, they are remarkably lightweight on account of a rather high and evenly distributed porosity, a characteristic also shared with the Maastricht stone. They are essentially used as cornerstones and their size is the largest of all regional building stones, up to $65 \times 50 \times 30 \mathrm{~cm}$ (Figs 2, 3). Their origin remained enigmatic until the Working Group Vuursteeneluvium discovered the same rock type at the bottom of a nearby sand pit. This was the start of the search for its stratigraphic origin and diagenetic history.

\section{Why a rock is called 'tauw'}

Definition of 'tauw' as a stone type is not based on petrographical criteria but rather derives from vernacular language, based on the shared experience of quarry workers: upon hitting with a hammer, the impact shock is not transmitted to the rock and does not result in creating fractures, with a rather uncomfortable strain effect on the hammer-wielding labourer. Etymologically, 'tauw' is derived from the verb 'taujan' (Gothic for 'work, keep busy'), via the Limburg dialect verb 'taw' (meaning getting one's

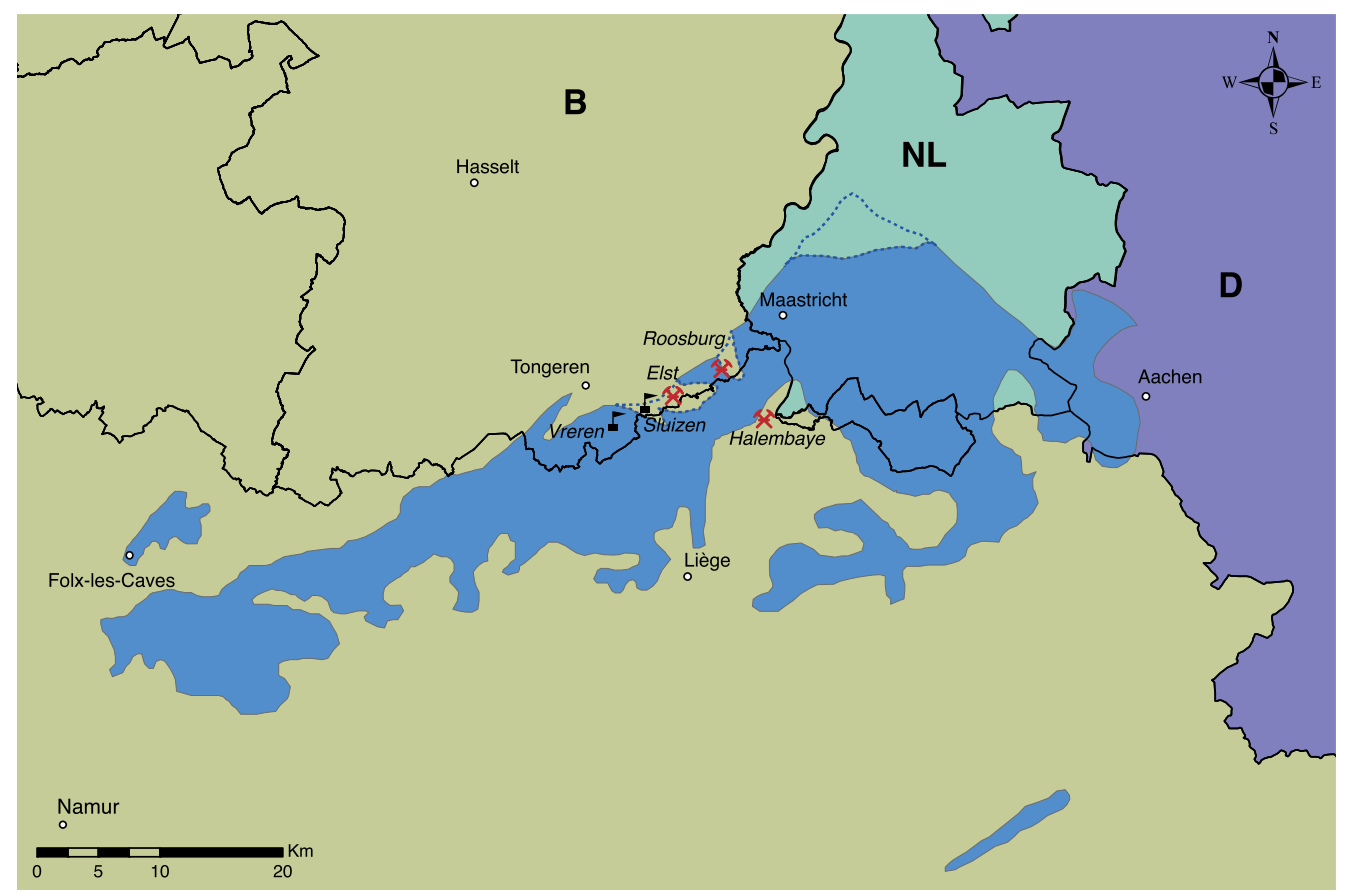

Fig. 1. Map of Cretaceous outcrop in the borderland between the Dutch 'Mergelland' (NL), the Hesbaye and Herve regions in Belgium ( $B$ ) and the Aachen district in Germany (D). The location of 'Elst tauw' as building stone is shown (Sluizen, Vreren), as well as in natural environment (Maurissen sand pit at Elst) and of Roosburg underground quarry (municipality of Zichen), with stratigraphically corresponding calcarenite facies. 


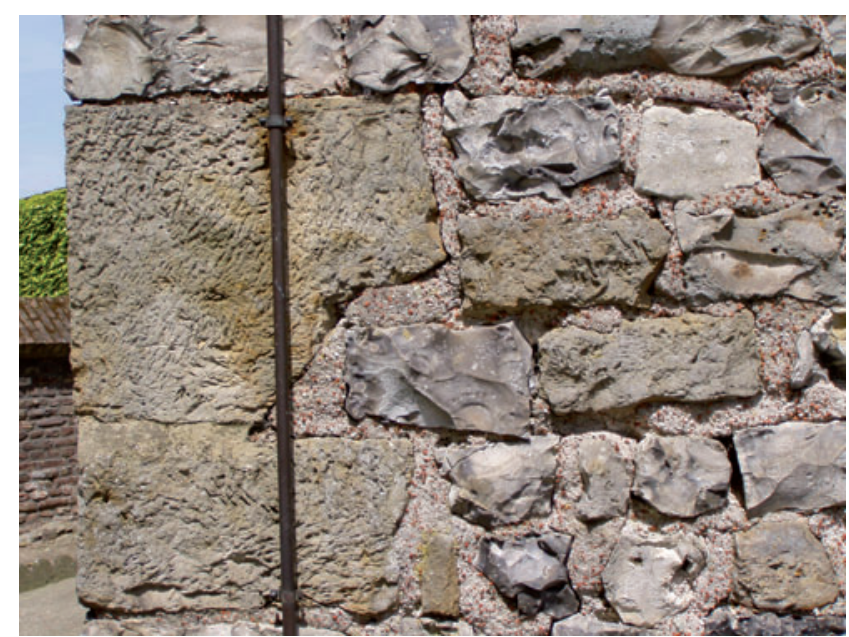

Fig. 2. St Servatius church at Sluizen, showing large chiselled blocks of 'Elst tauw', adjacent to normal-sized flint blocks.

share of a burden, being wearisome; see Jaspars, 1985; Weijnen, 1996). The word has nothing to do with the Latin word 'tofus' (tuffaceous rock), which applies to the Maastricht stone, also occasionally referred to as tuffaceous chalk (tufkrijt), nor with the modern Dutch word 'touw' (rope), although freely (mis-) interpreted as a twisted rock, spread like a series of threads

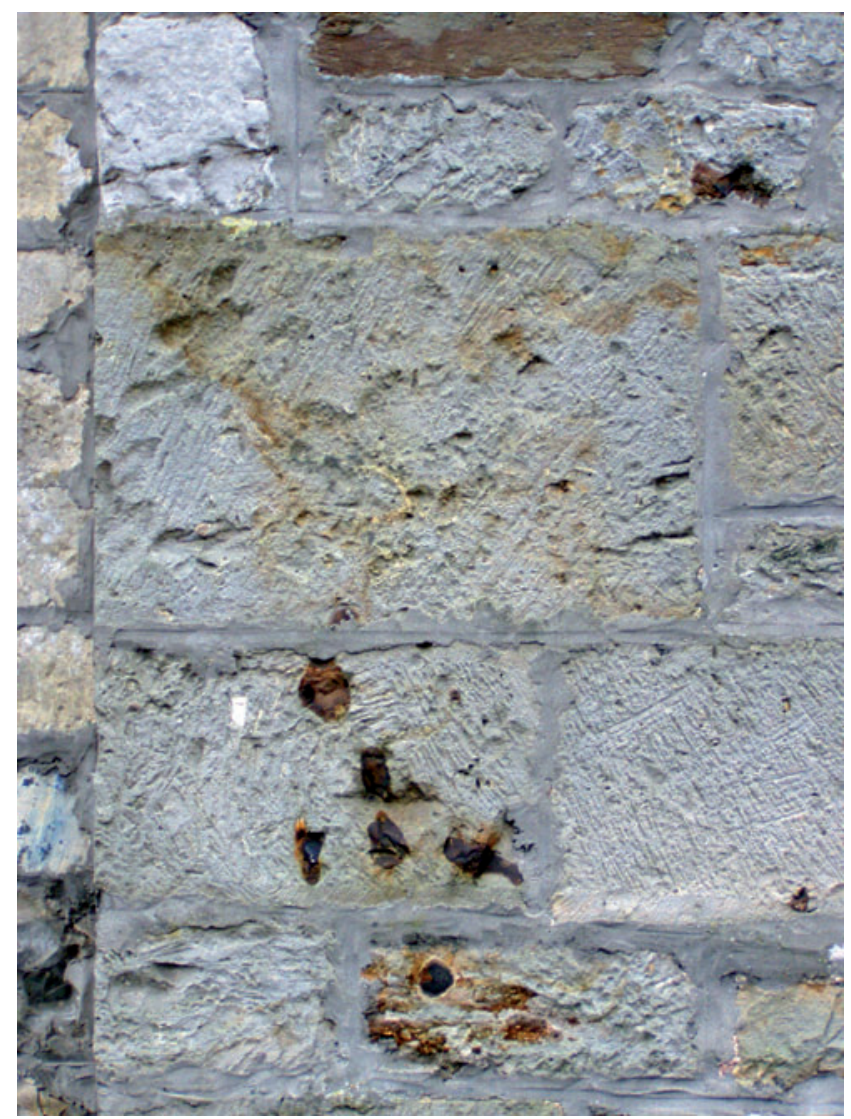

Fig. 3. St Medardus church at Vreren, showing large chiselled blocks of 'Elst tauw' containing dark flint nodules, displaying rusty brown weathering colour due to alteration of pyrite which is mostly concentrated in the flint nodules. through the calcarenitic deposits of the Maastricht Formation, and hence seen as continuous horizons or reference levels. Based on this reasoning, 'tauw' has been used as a synonym for hardground, suitable as a reliable roof in underground quarrying (Bosch, 1989; W.M. Felder \& Bosch, 1998; see also Keuller, 1912).

This vernacular or geological definition already hints at its mechanical properties, but does not say anything about its chemical composition. It has caused some duality in geological and architectural terminology. In quarrymen language 'tauw' is a stratiform rock suitable as roof support in subterranean quarries, and generally composed of carbonate. In the building stone inventories of historical buildings, 'tauw' is typified by its peculiar mineral composition, in which silica is preponderant, and by its porous texture, not by its origin. It is thus necessary to specify the application fields for this particular name. 'Tauw' as a building stone type is not equivalent to the hardgrounds of the Maastricht Formation, since not all hardgrounds are silicified, nor did they produce building stones. Moreover, some 'tauw' varieties have a different geological history, particularly the stone type described in the present study.

Although 'tauw' and 'heerd' are often used as interchangeable names in the literature, in practice this is rarely the case. Klein (1911) used 'heert' (sic) for well-cemented carbonates of the Maastricht Formation which were the result of dissolution and precipitation cycles. Keuller (1912) reserved the name 'heerd' for non-stratiform, compact limestones, still resembling the Maastricht calcarenite, and 'tauw' for stratiform horizons, or hardgrounds, separating the various porous calcarenitic units. Unfortunately, he did not comment on the degree of silicification. Keuller described compact limestone around karstic sinkholes which best corresponded to his definition of 'heerd'. Macar (1947) identified two hardgrounds in the upper part of the Maastricht Formation (possibly corresponding to the Kanne and Caster horizons) as 'tauw'. However, in the description accompanying his stratigraphic scheme, he distinguished two different types of 'tauw', mentioning 'heerd' as the Dutchlanguage equivalent: one type of 'tauw' effectively occurring as stratiform beds, another forming a thick crust around karstic dolines. His petrographical description of crystallised limestone (sparite-cemented) probably refers to the latter type. Slinger et al. (1980) also used both names for compact beds within the softer calcarenitic ('mergel') deposit. However, those authors restricted the name 'tauw' to fossiliferous beds, excluding the well-cemented, finer-grained calcarenites that are more closely similar to the Maastricht limestone. Compact, strongly crystallised limestones (supposedly formed around karstic surfaces), such as the massive, creamy white limestone blocks observed along the south and west walls of St Servatius church at Maastricht) are known as 'heerd' (Keuller, 1912; P.J. Felder, pers. comm., July 2006). It is thus obvious that the term 'heerd' is to be reserved for such massive, well-cemented carbonates; these are not considered further in the present study. 
'Tauw', or 'tawe' in Walloon, reflects the difficult workability of the rock (Keuller, 1912). Therefore, further usage of this name for a building stone type should thus be restricted to rather 'tough' ('taai' in Dutch) silicified carbonate rocks occurring within the Maastricht Formation.

\section{Discovery of 'tauw' underneath the Clay-with-flints at Elst}

On the Hesbaye Plateau, north of the valley incised by the River Jeker, the Cretaceous deposits are often covered by north-dipping Oligocene sands whose geometric position is influenced by block faulting and epikarstic dissolution of the top Cretaceous. On one of the culminating points of the northern Hesbaye Plateau (at 149 m above sea level or 151.20 m +NAP) near the hamlet of Elst in the village of Millen, sand was quarried at the Maurissen pit; this provided a temporary outcrop down to the top Cretaceous during 25 years. This outcrop is registered under GeoDoc number 107W0304 in the database of the Geological Survey of Belgium; additionally, it was described in 1992 by W.M. Felder as outcrop 61G-15 in the original database of the Geological Bureau Heerlen (the Netherlands). Below $4 \mathrm{~m}$ of colluvial loam and loess, two sand deposits, $8 \mathrm{~m}$ and $9 \mathrm{~m}$ thick, respectively, show facies characteristics of the Boncelles and Neerrepen sands, respectively. These undated sands were mapped together as the St. Huibrechts-Hern Formation on the new geological map of Belgium-Flanders (Claes et al., 2001). Below these sands, presumed of Oligocene age, $1 \mathrm{~m}$ of Claywith-flints occurs. This deposit is the result of dissolution of the carbonate matrix, leaving a more or less stratiform concentration of flint embedded in clay-rich impurities and often subject to palaeosol alteration (Van den Broek \& Van der Waals, 1967; Catt, 1986; Quesnel, 1997: 'argile à silex'; also described as 'chert/terra rossa breccia' (Knauth, 1994), or 'residual chert deposit' (Van der Ham et al., 2007)). This deposit is locally known as 'flint eluvium' (vuursteeneluvium). At Elst, only the very pure Maastricht calcarenites contribute to the formation of this weathering residue, hence it is rather thin and poor in clay. Despite the low clay content, the local accumulation of flint nodules can be correlated without doubt to the Clay-with-flints lithostratigraphical unit.

The irregular top of the Cretaceous deposit was reached at c. $24 \mathrm{~m}$ depth (i.e., $125 \mathrm{~m}$ above sea level). The maximum height of Cretaceous strata exposed was $3.25 \mathrm{~m}$, consisting of yellow calcarenite with nodular flint layers. In elevated positions, in between epikarstic depressions, the calcarenite is covered by a crust of porous rock with a sandstone appearance, representing silicified calcarenite enclosing small flint nodules of purplish colour, henceforth named the 'Elst tauw' (Fig. 4). Remarkably, some flint nodules are zoned, showing an outer dark layer extremely rich in finely disseminated pyrite (Fig. 5). This 'tauw' layer broke into blocks, the largest of which measured up to $2 \times 1 \times 0.5 \mathrm{~m}$ (Fig. 4). It generally is of a yellow hue, but displays

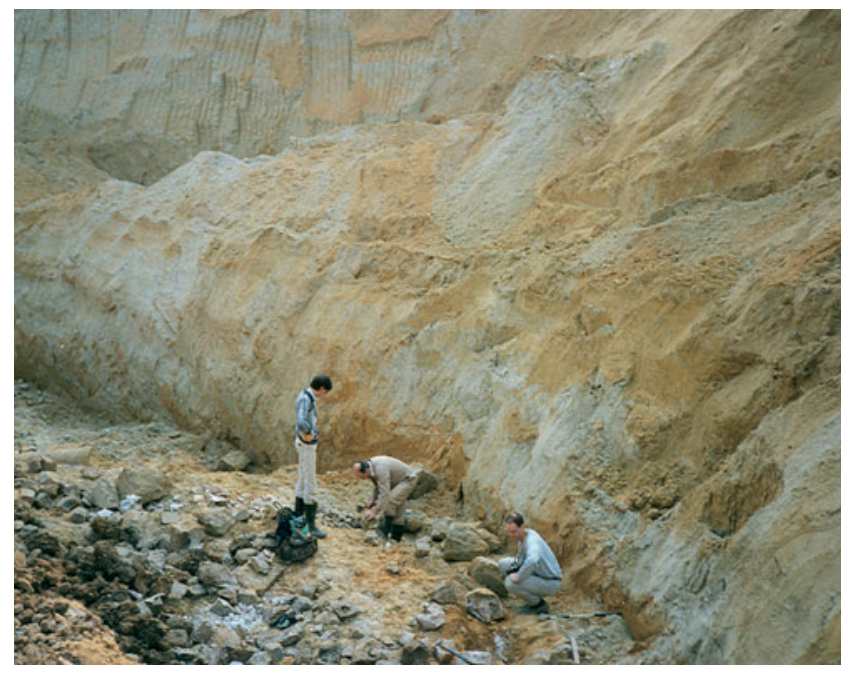

Fig. 4. Extracting fossils from displaced 'tauw' blocks at the bottom of Maurissen sand pit at Elst (community Millen) (photograph by Edwin Defour, 1991).

many colour variations related to the weathering effect of meteoric water circulation, from creamy white to orange brown (Fig. 6), occasionally displaying a Liesegang-type banding not related to the original bedding (Fig. 7). Both the Clay-withflints and the 'tauw' proved to be highly fossiliferous, although collecting from the latter was extremely difficult, requiring the use of a heavy hammer $(5 \mathrm{~kg})$, and not very rewarding because fossils are rather dispersed in the rock matrix.

\section{Material and methods}

\section{Petrography}

Two samples were collected from the St Servatius church at Sluizen, following recent restauration works. Five samples from the Maurissen sand pit at Elst were selected from a much larger collection, registered as 'Elst no. 32' by members of the Working Group Krijt \& Vuursteeneluvium. All selected samples show characteristics of 'tauw' and bear good visual resemblance to the Sluizen samples. Thin sections for optical microscopy of 'tauw' samples were made at the Geology Laboratory of Brussels Free University (ULB), of the Roosburg calcarenite by the Royal Institute for Cultural Heritage, and photographed with an Axiocam digital camera (Zeiss) mounted on a Zeiss Axioplane2 polarizing microscope at VITO. The micrographs (macroscopical shots) were taken with a digital camera (Zeiss Axiocam) mounted on a Zeiss Stemi binocular optical microscope at VIT0. The 2D-porosity has been measured by means of automated image analysis (Axiovision 3.0) at VITO. Scanning Electron Microscope (FEI Quanta 200 installed at RBINS) photographs were made in Low Vacuum as Back Scatter Images (BSD), representing mostly the electron density, or Secondary Electron Images (SE), representing surface differences (the latter not included in the illustrations). SEM chemical analyses 


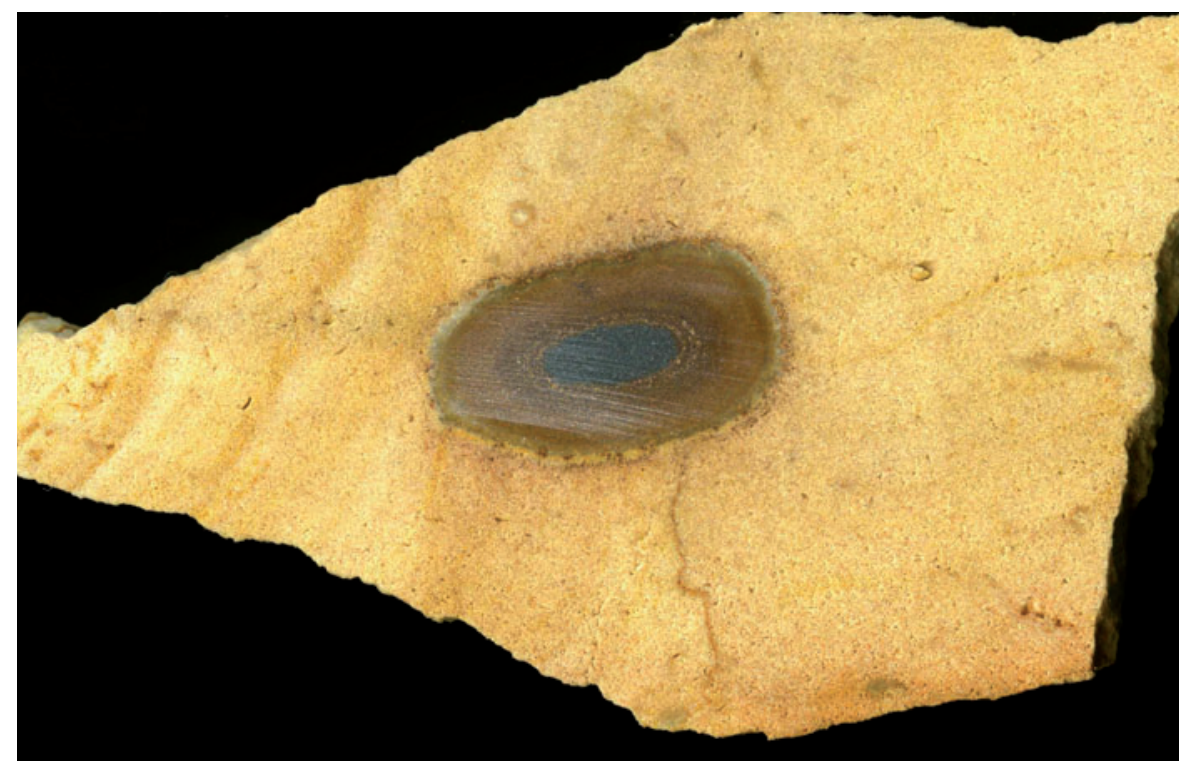

Fig. 5. 'Elst tauw' from the Maurissen sand pit: cut surface in yellowish white (when dry, rather orange yellow when wet) rather dense, medium-grained, silicified calcarenite with large pores, dissolved serpulid with internal fill; vague rusty brown large-scale (almost metric) Liesegang rings; with zoned flint nodule (2 cm diameter) with grey core, dark purplish brown rings with lighter quartz speckles, more homogenous purplish brown mantle with discoloured rim and finally dense caramel brown crust with indentations and patches of rusty brown more porous transition zone to silicified calcarenite. The purplish brown colour is due to disseminated pyrite (R. Meuris Collection).

were made with an Energy Dispersive System (EDS) of EDAX with Apollo 10 detector (Silicon Drift detector) and Genesisanalysis software. The studied samples and thin sections are kept in the collections of the Geological Survey of Belgium (Brussels; 'tauw' from Sluizen as 0222 in the building stone collection; 'tauw' from Elst under 107W0304 in the lithological library).

\section{Palaeontology}

In view of the fact that the fossils themselves are mostly dissolved but their impressions superbly preserved as external and internal moulds, silicone casts were made for taxonomic studies from flint samples. Sample preparation included rinsing, dissolution of remaining calcite with hydrochloric acid, ultrasonic cleaning, brushing a water repellent on the fossil impressions, followed by gluing together the smaller parts of broken rock, keeping the larger parts in place with elastic rings and replacing lost pieces by a paste, leaving only a single opening in the mould through which silicone rubber was injected. The two-component silicone is mixed and passes into a vacuum vessel of an excicator for removal of air bubbles before injection into the mould. The injected sample can also make a passage into the vacuum vessel. Hardening takes between 2 and 24 hours, after which the white silicone cast can be carefully removed from its containing pieces of rock, to avoid small cracks. This two component silicone has been selected for its low viscosity and high shear stress. Moreover, it is possible to produce several casts of the same fossil mould (www.mctechnics.com; www.wacker.de; www.dowcorning). Because of the larger grain size and porosity of 'tauw', causing high surface rugosity, no silicone casts were made of this material, but rather internal moulds ('steenkernen') were used for identification. Illustrated 'tauw' samples were photographed with a Nikon Coolpix 995 after wetting. Rock samples and silicone casts are retained in collections held by members of the Working Group Krijt \& Vuursteeneluvium.

Fig. 6. 'Elst tauw' from the Maurissen sand pit: cut surface (largest diameter $10 \mathrm{~cm}$ ) in orange brown, strongly porous 'vuggy' silicified calcarenite with frequent moulds of dissolved fossils (thin shells, serpulids, cidarid echinoid), displaying pedogenic weathering (R. Meuris Collection).

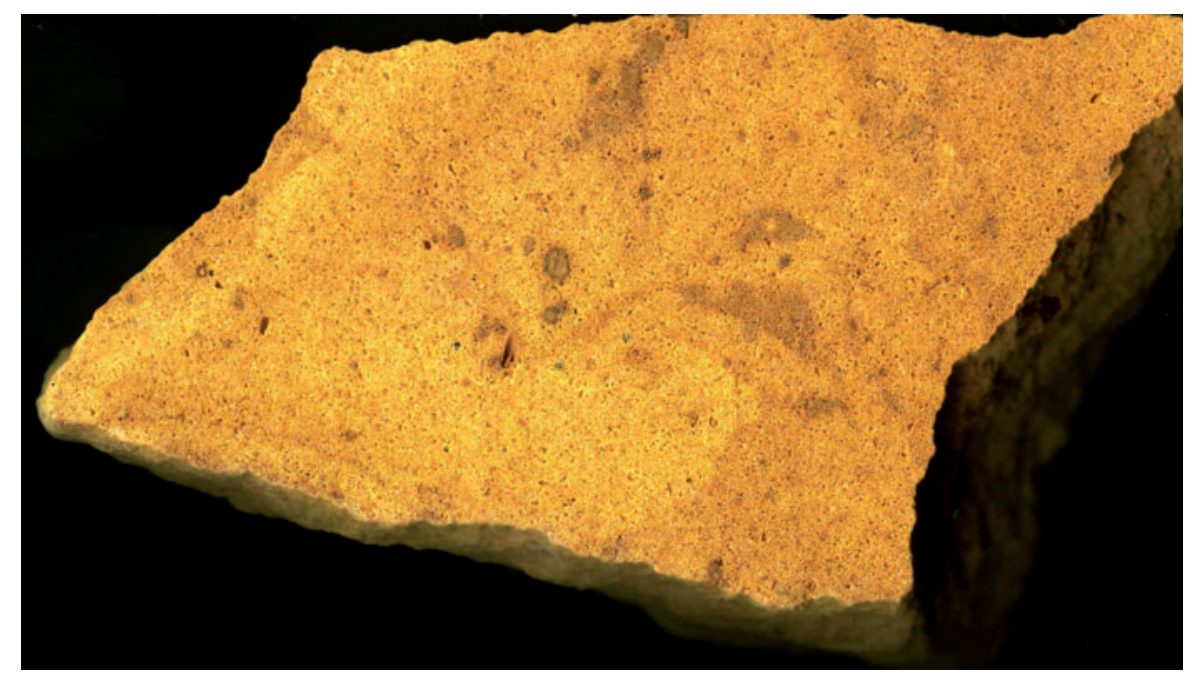




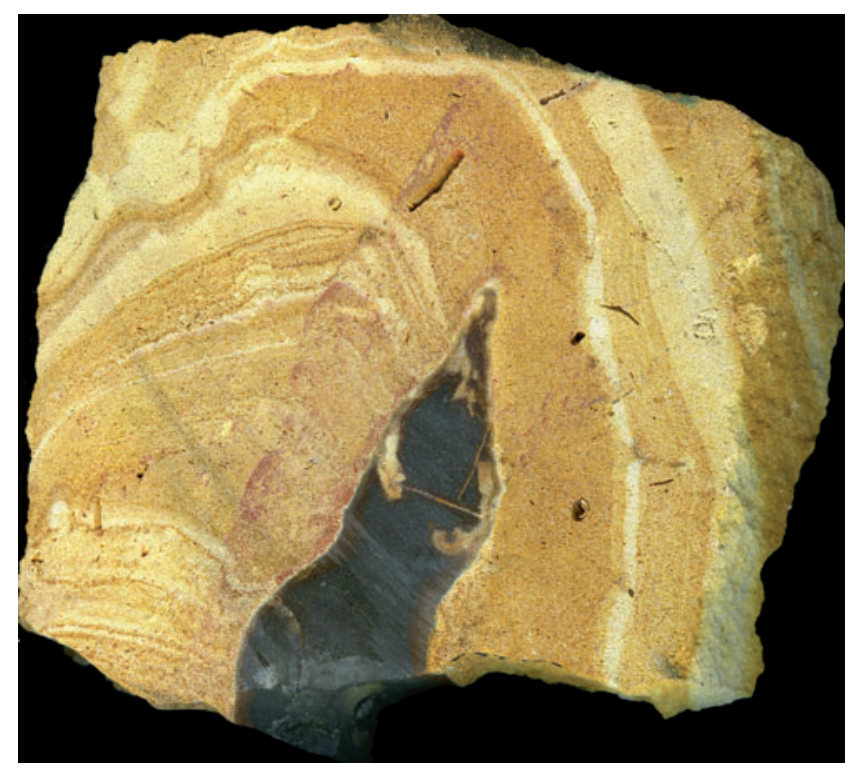

Fig. 7. 'Elst tauw' from the Maurissen sand pit: cut surface (largest diameter $10 \mathrm{~cm}$ ) in silicified mouldic bioclastic limestone with Liesegang rings crossing flint nodule, brown bands being more porous; flint nodule showing grain texture comparable in size to the surrounding matrix, with outer purplish brown coloured band and whitish front in the silicified calcarenite; reddish oxidation fronts away from the flint (L. Indeherberge Collection).

\section{Stratigraphic assignment}

The temporarily exposed calcarenite at the bottom of the Maurissen sand pit was sampled by the late W.M. Felder for benthic foraminiferal analysis by the late J.P.M.Th. Meessen (Geological Bureau (Heerlen) report of outcrop 61G-15). Two samples yielded benthic foraminifera typical of foram zone H of Hofker (1966), characterising the Valkenburg, Gronsveld and Schiepersberg members or the lower part of the Maastricht Formation, below the Romontbos Horizon (i.e., the base of the Emael Member) (Fig. 8). In the River Jeker valley, the Valkenburg and Gronsveld members together account for a thickness of $4.50 \mathrm{~m}$. At the Maurissen sand pit, $3.25 \mathrm{~m}$ of the lower Maastricht Formation was exposed, implying that the contacts with the underlying Lanaye Member (Gulpen Formation) and the overlying Emael Member (in fact removed by erosion) must have been close. Because the 'tauw' layer is genetically related to this sequence within the lower Maastricht Formation, it can be assumed to represent either the Gronsveld or Schiepersberg (if present) member. This deduction is corroborated by macrofossil studies.

The macrofauna collected from the 'tauw' at the Maurissen pit is fairly unique because it cannot be readily compared to stratigraphically similar assemblages from flint elsewhere in the Mergelland. Due to working conditions in displaced rocks at the bottom of a deep sand pit, not paying particular attention to 'tauw' at any time, fossil records encompass both 'tauw' and Clay-with-flints (Fig. 8). It is assumed that the basal layers the latter unit include flints originating from the lower Maastricht Formation (i.e., time equivalent to the 'tauw' deposit, possibly even stemming from a slightly lower stratigraphical level than that, due to deeper epikarstic dissolution postdating the diagenetic transformation of the 'tauw' bed) up to the top of the Nekum Member in the upper Maastricht Formation, i.e., the stratigraphically highest flint-bearing calcarenite. Taking into consideration that the Emael and Nekum members contain fewer flint nodules than the lower members of the Maastricht Formation, a close faunal similarity of 'tauw' and the Clay-withflints is acceptable in this case. In order to refine the stratigraphic position of the 'tauw' level at Elst, or the top of the Cretaceous exposed there, the fossil frequency distribution list (Table 1) can be compared with echinoid faunas of the underlying Lanaye Member and overlying Nekum Member from better-known localities where Clay-with-flint deposits are accessible, at (Fig. 1) Halembaye, Sluizen (various outcrops along the River Jeker valley) and Zichen-Eben Emael, overlying the Roosburg subterranean quarry, in order to discern trends in frequency distribution (Van der Ham et al., 2006). However, evaluations may be biased towards larger-sized specimens. Also, very large collections from the Lanaye Member, well exposed in the Clay-with-flints at Halembaye, are certainly more representative than the relatively small set (530 echinoid specimens in total) from the Elst sand pit:

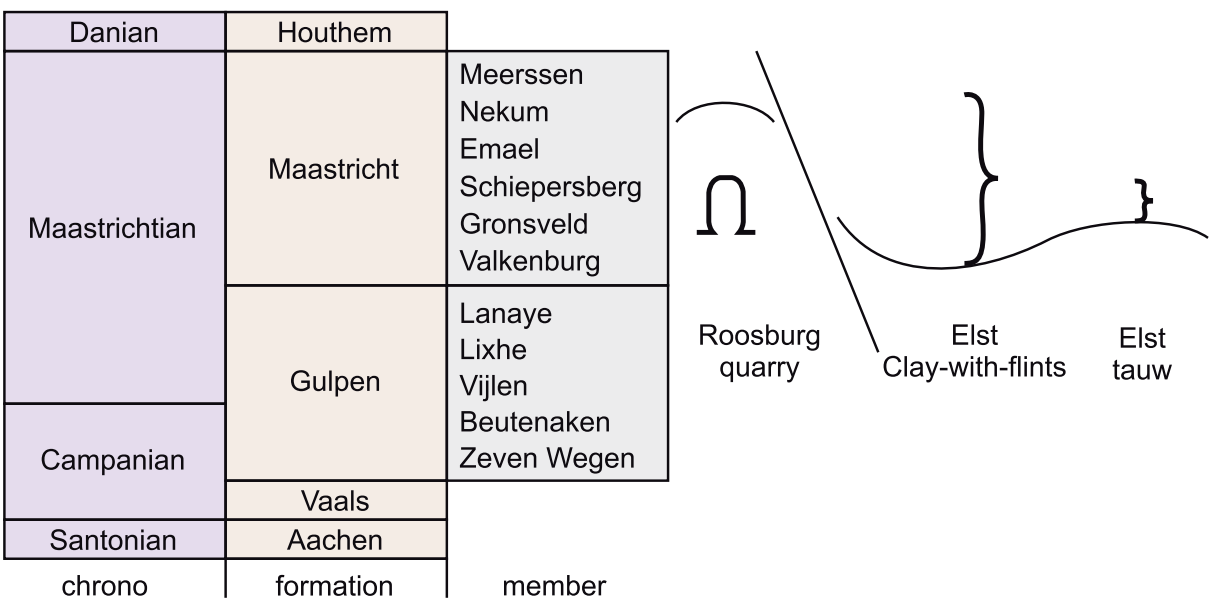

Fig. 8. Simplified lithostratigraphic scale of the Chalk Group in the Mergelland, showing stratigraphic position of the Roosburg underground limestone quarry at Zichen and strata represented in the Clay-with-flints compared to the 'tauw' encountered at the Maurissen sand pit at Elst. In the study area, the lower members of the Maastricht Formation (Valkenburg to Schiepersberg) cannot be differentiated on lithological grounds (after W.M. Felder, 1975). 
- echinoid species not found at Elst but common in the Lanaye Member (lower part, i.e., below flint layer 16) are Diplodetus bucardium, Hemiaster prunella, Oolopygus sp. (low-lying anus), Echinocorys scutata, in addition to (upper part, i.e., above flint layer 16) Hemiaster aquisgranensis, Hemipneustes oculatus, Cardiaster rutoti and Cardiaster sp.;

- common in the Lanaye Member, but rare at Elst are Diplodetus parvistella and Diplodetus duponti;

- occurring frequently in the Lanaye Member, but commoner at Elst are Oolopygus pyriformis (Fig. 14/3), Hemiaster koninckanus, Leymeriaster eluvialis (Fig. 14/1), Hemipneustes striatoradiatus (Fig. 14/2), Cardiaster granulosus, Gauthieria radiata (Fig. 14/7) and Nucleopygus scrobiculatus;

- rare in the Lanaye Member, yet common at Elst are Procassidulus lapiscancri (Fig. 14/8), Faujasia apicalis and Rhyncholampas macari (Fig. 14/5, 6);

- 'new' species at Elst, unknown from the Lanaye Member elsewhere, is Leymeriaster maestrichtensis;

- extremely rare at Elst (a single specimen each) are Catopygus subcircularis (otherwise known only from the Kunrade limestone) and Trochalosoma mortenseni.

Other macrofaunal groups that appear first at Elst and are yet unknown from the Lanaye Member, or are commoner at Elst, include thalassinidean crustaceans such as Protocallianassa faujasi (Fig. 14/4), baculitid ammonites, sponges, gastropods and bivalves, among which Tenuipteria argentea is common. According to Dhondt (1979) this species has an uncertain stratigraphic range in the area; however, Jagt (1999) noted that it might be confined to the Meerssen Member, with the closely related Spyridoceramus tegulatus ranging from the upper Vijlen Member to the top of the Nekum Member (see also Walaszczyk et al., 2010).

Echinoids from Elst which become commoner upwards in the Maastricht Formation (as recorded from the Clay-with-flints of the Nekum Member in the Zichen-Eben Emael) area are Procassidulus lapiscancri, Hemipneustes striatoradiatus, Faujasia apicalis, Nucleopygus scrobiculatus, Leymeriaster maestrichtensis and Rhynchopygus marmini (a single specimen from Elst). In addition, cephalopods and gastropods are encountered more frequently higher in the Maastricht Formation.

From this comparison it is obvious that the echinoid fauna recorded from the Clay-with-flints and 'tauw' at Elst is slightly younger than assemblages from the Lanaye Member (Gulpen Formation). A few species common in the Maastricht Formation remain rare at Elst. Despite the fact that these are different geographic areas, there is some overlap in species distribution with the Kunrade limestone, as judged from very rare forms, that unit being mainly time-equivalent of the lowermost Valkenburg Member (Maastricht Formation). This, correlation of the Clay-with-flints at Elst, as well as the 'tauw' layer there, with the Valkenburg to Schiepersberg interval at the base of the Maastricht Formation appears justified (Fig. 8).
Table 1. Fossil record (mainly echinoids) with number of specimens from the 'tauw' bed and flint eluvium in the Maurissen sand pit at Elst (GeoDoc 107W304; Archive 32 of Working Group Krijt \& Vuursteeneluvium). - = those species that with certainty are recorded from the 'tauw' bed.

\begin{tabular}{lll}
\hline Irregular echinoids & 176 & $\bullet$ \\
Oolopygus pyriformis & 111 & $\bullet$ \\
Procassidulus lapiscancri & 73 & $\bullet$ \\
Cardiaster granulosus & 54 & $\bullet$ (rare) \\
Hemiaster koninckanus & 50 & $\bullet$ \\
Leymeriaster eluvialis & 45 & $\bullet$ (common) \\
Rhyncholampas macari & 27 & $\bullet$ \\
Hemipneustes striatoradiatus & 6 & $\bullet$ (rare) \\
Nucleopygus scrobiculatus & 6 & $\bullet$ \\
Faujasia apicalis & 4 & \\
Diplodetus parvistella & 3 & \\
Hemiaster maastrichtiensis & 3 & \\
Diplodetus duponti & 1 & \\
Rhynchopygus marmini & 1 & \\
Nucleopygus coravium & & \\
\hline Regular echinoids & & \\
Gauthieria radiata & 68 & \\
Salenia sp. & 2 & \\
Trochalosoma mortenseni & & \\
\hline Crustaceans & & \\
Protocallianassa faujasi & & \\
\hline Ammonites & & \\
baculitid & & \\
\hline Belemnites & & \\
\hline Serpulids & & \\
\hline Pyrgopolon mosae & & \\
\hline Plants (seagrass) & & \\
\hline
\end{tabular}

\section{Petrographical description}

\section{Silicified limestone ('Elst tauw')}

All samples studied (Maurissen pit outcrop (Figs 5-7) as well as Sluizen building stones (Figs 9, 10)) are analogous. However, a clear distinction can be made between the porous, silicified limestone matrix and the non-porous nodular flint inclusions (Figs 11-13; Micrographs 1-16; SEM images 23, 24). The contact zone between both rock types is marked by a gradual transition, contrary to the more distinctive change between unaltered flint and soft calcarenite (Figs 12, 13; SEM image 23). All samples display an orange-yellow weathering colour, due to a pervasive oxidation of the pyritised allochems to limonite. The original limestone (prior to silicification) was a biosparite or bioclastrich grainstone, characterised by an important interparticle and intraparticle primary porosity. Besides plurilocular foraminifera, also fragments of bivalves, echinoderms and bryozoans can be 


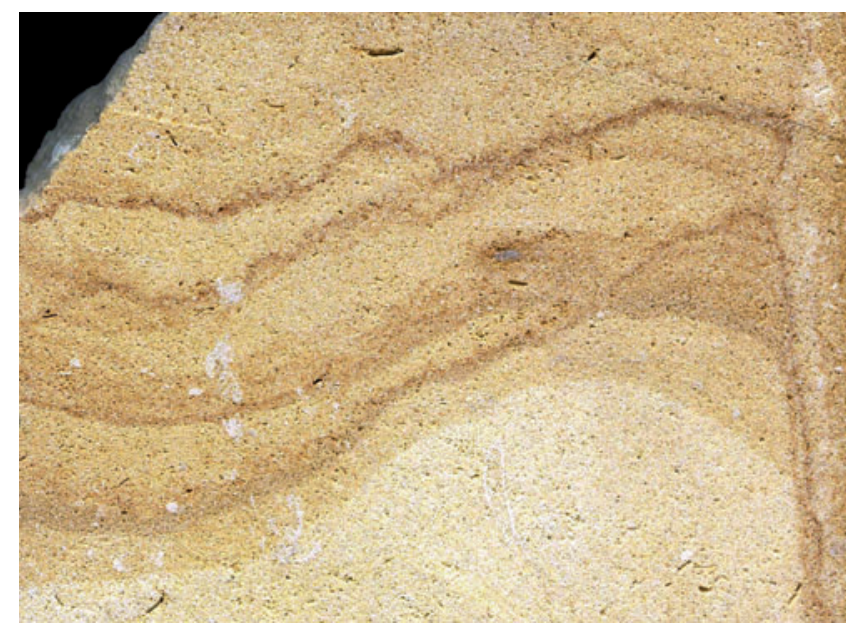

Fig. 9. 'Elst tauw' from St Servatius church at Sluizen: cut surface (width $10 \mathrm{~cm}$ ) in creamy-white silicified mouldic-bioclastic limestone, still containing calcitic allochems, displaying brown Liesegang rings which concentrate iron and insolubles, possibly developed after extraction (RBINS building stone collection 222).

distinguished (Fig. 11; Micrograph 1; SEM images 27, 28). Early in the diagenetic history, the primary pore space was clogged with silica, displaying varying mineralogical habitus and grain sizes: microcrystalline quartz (microquartz), macrocrystalline quartz (megaquartz), cryptocrystalline quartz and fibrous cryptocrystalline quartz (chalcedony). The bulk of the cement is formed by micro- to cryptocrystalline quartz (SEM images 29, 30). Chalcedony and megaquartz filled the large pores at a later stage (SEM images 33,34). In the dense silica-rich cores of the flint nodules the cement consists of more fine-grained silica (microquartz) alternating with chalcedony and megaquartz, also recognisable macroscopically (Micrographs 5-7, 9, 10;

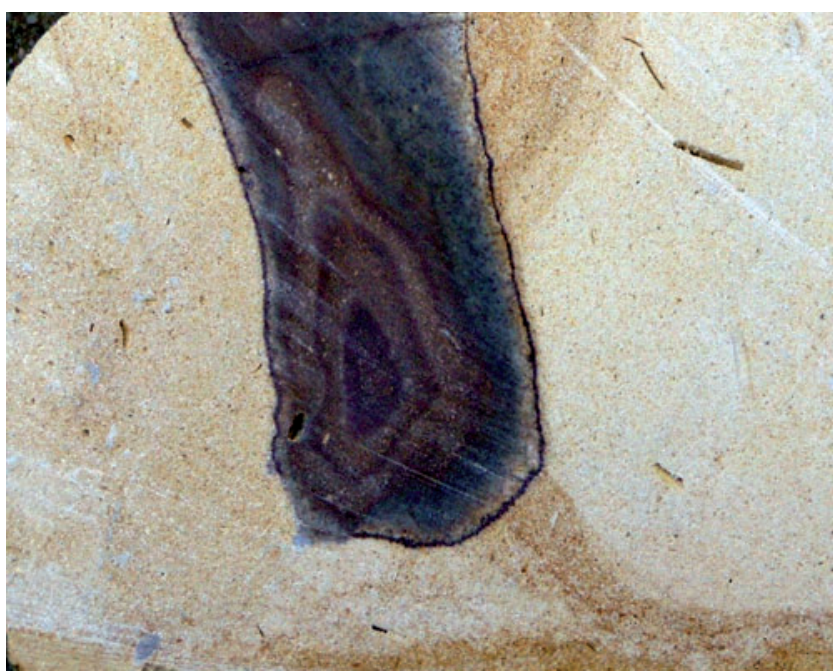

Fig. 10. 'Elst tauw' from St Servatius church at Sluizen: cut surface (width of flint nodule $3 \mathrm{~cm}$ ) in light yellowish brown silicified mouldic bioclastic limestone containing elongated, purplish zoned flint nodule. Matrix silicification provides strong bond between original flint and surrounding tauw (RBINS building stone collection 222).

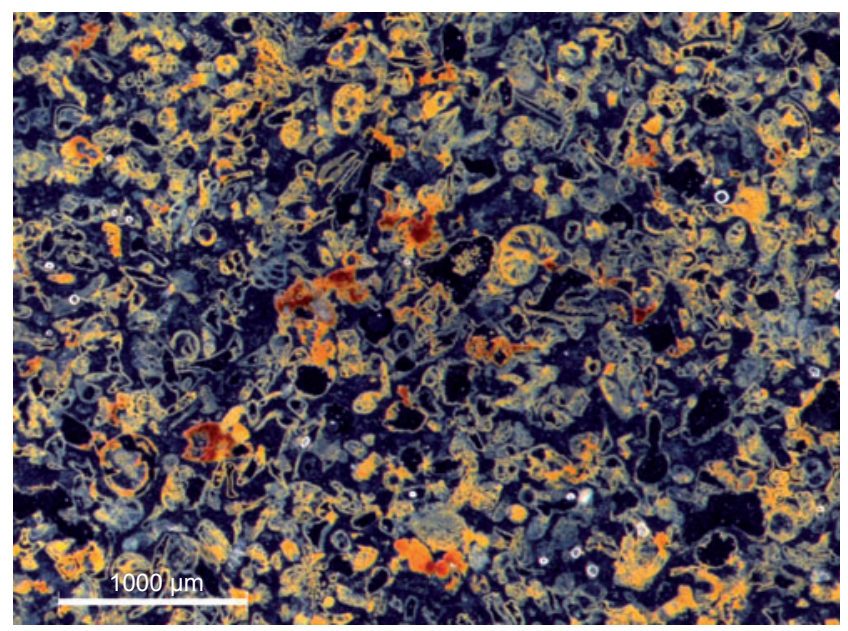

Fig. 11. Macroscopical (binocular) view of a thin section in the 'Elst tauw' from the Maurissen sand pit (see Fig. 6): the contours of the skeletal grains (bioclasts) such as plurilocular foraminifera and echinoderm fragments are well recognisable due to the brown-orange limonite impregnation. The dark-grey matrix is silica. The darkest grey areas are voids or pores (moulds). Normal transmitted light. Scale bar for magnification.

SEM image 25). Calcite remnants are still present as inclusions in the quartz. In the samples of the building stone a few original calcareous allochems occur that were not affected by pyrite impregnation.

A large portion of the calcareous skeletal allochems has been (partially or totally) replaced by pyrite, prior to silicification. The original skeletal allochems remain recognisable because their external surfaces have been impregnated with pyrite or a limonitic rim (Micrographs 1-4, 11-13). Ghost images of the silicified bioclasts can still be identified because of the presence of these impurities.

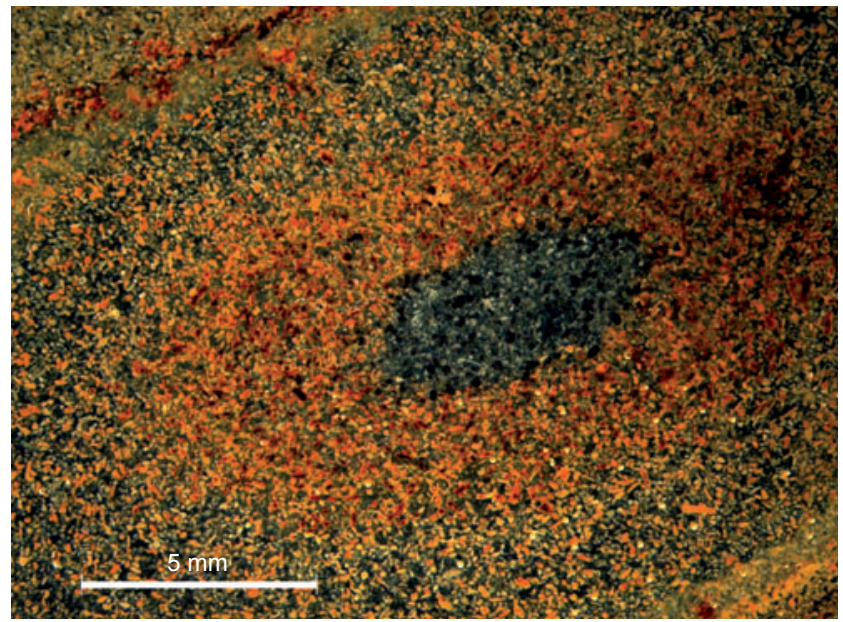

Fig. 12. Macroscopical (binocular) view of a thin section in flint nodule of the 'Elst tauw' from the Maurissen sand pit (see Fig. 5): concentric liesegang type of discoloration due to varying intensity of limonite staining of the skeletal grains, varying silica content (cement) and differences in porosity. Note unweathered (dark grey) and non-porous core of the flint nodule. Normal transmitted light. Scale bar for magnification. 


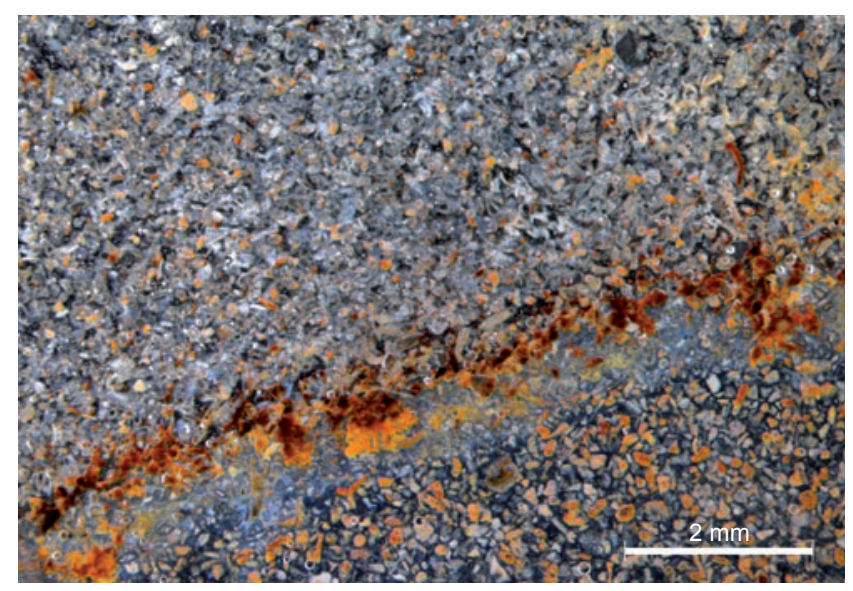

Fig. 13. Macroscopical (binocular) view of a thin section in a flint nodule of the 'Elst tauw' from the Maurissen sand pit. Detail of previous micrograph (uppermost left-hand corner). Concentration of brown-orange limonite in transition or contact zone of less (top) and more (bottom) silicified parts of the flint nodule. Dark-grey matrix between limonite-stained skeletal allochems corresponds to silica cement. Normal transmitted light. Scale bar for magnification.

The original habitus of the pyrite crystals is not clear but locally a framboidal texture can be assumed. This is best observed in the non-weathered, non-oxidised cores of the flint nodules. The allochems are not oxidised and are still impregnated with pyrite, resulting in a dark-grey colour of the silica (Micrographs 8 , 14-16; SEM images 24, 25). The pyrite content approaches 4 per cent. 0xidation of the silica-rich cores is restricted to their external zone (contact zone with the more porous and lesssilicified limestone), macroscopically indicated by the purplish colour of the flint nodules. The banded aspect of some flint nodules (showing a brown external zone and a grey core) most probably results from oxidation of pyrite in the contact zone with the silicified limestone. This is repeated by the rusty brown to red bands, speckled with limonite precipitates (SEM image 26), surrounding the flint nodules (Figs 12, 13; SEM image 23).

The silicified limestone and the outer zone of the flint nodules display an important secondary porosity (mouldic porosity) due to the dissolution of limonitised calcareous bioclasts (SEM images 27, 28). As a result of silica recrystallisation, the mouldic pores do not match necessarily the exact form of the original bioclasts (SEM images 31, 32). The macroporosity (pores $>1$ micrometre) of the silicified limestone (excluding the flints) has been measured by means of $2 \mathrm{D}$-automated image analysis and ranges from 12.3 to 12.7 per cent.

Based on these microscopical observations, the following scenario can be suggested for the diagenetic history of this particular rock type. However, it is a preliminary scenario that needs to be confirmed by further detailed petrographicalgeochemical analysis, concerning its timing and possible recurrence:

1. Pyritisation of the original calcareous allochems (and glauconite, if present); in the presence of sulphate-reducing bacteria, dissolving calcareous skeletal grains act as nucleation substrates;

2. Silicification of the grainstone fabric: filling of the primary inter- and intraparticle pore volume by different silica cements: first cryptocrystalline and/or microcrystalline quartz, later chalcedony and finally megaquartz. It is possible that part of the original cryptocrystalline quartz was recrystallised into megaquartz;

3. Oxidation of pyrite (possibly also of glauconite, if present) and transformation into limonite, resulting in orange-brown to orange-yellow ('ochre') weathering colours, associated with the formation of Liesegang rings;

4. Dissolution of the non-pyritised or partially pyritised skeletal allochems, by sulphuric acid originating from pyrite oxidation. This selective dissolution would then lead to an increase of the porosity (mouldic porosity);

5. Silicification of the secondary mouldic porosity, at least partially, by microquartz and finally megaquartz.

These diagenetic events affecting the transformation of original bioclastic, fossiliferous calcarenite into 'tauw' took place under shallow burial and meteoric or mixing zone conditions. The principal silicification phase must have occurred after dissolution of the major part of the Maastricht Formation and formation of the Clay-with-flints residual deposit had lowered the top of the Maastricht Formation to the present stratigraphic level. Moreover, the silicification of 'tauw' seems to precede deep epikarstic dissolution, having been preserved only at the higher grounds around dolines.

\section{Roosburg block from Zichen, the unsilicified analogue}

The Maastricht stone of the Roosburg subterranean quarry is a very porous bioclastic grainstone, locally displaying packstone textures (microsparitic matrix still present; Micrographs 17, 21). The grainstone contains some large intraclasts of a planktonic foraminiferal wackestone (fine-grained chalky limestone). Their size reaches 500 to 900 micrometre (Micrograph 19). The size of the skeletal allochems or bioclasts ranges between 60 and 200 micrometre. Besides the above-mentioned large intraclasts, numerous smaller, partially micritised, intraclasts occur, with the same grain size as the skeletal allochems. Possibly, these intraclasts result from a complete micritisation of the skeletal grains. The origin of the latter skeletal grains is rather difficult to determine: several species of small benthic plurilocular forams are well recognisable, besides numerous skeletal fragments of echinoderms, bryozoans and bivalves. Rare sponge spicules have been observed as well. The bioclasts are locally partially pyritised and weathered to brown limonite (originally framboidal pyrite?), preferentially echinoderm fragments and plurilocular foraminifera with their important interparticle porosity. Quite remarkable is the presence ( $<5$ per cent) of fresh or only slightly oxidised glauconite grains (with pyrite inclusions) and the 


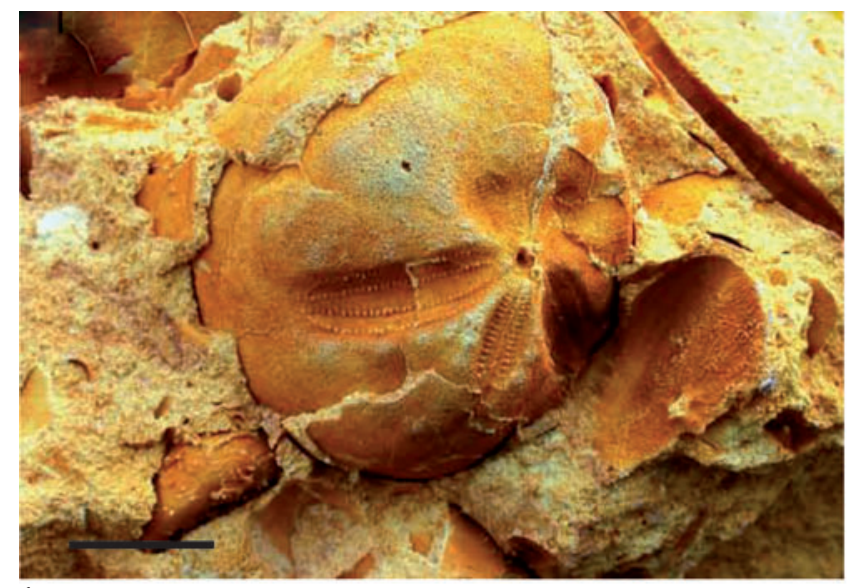

1

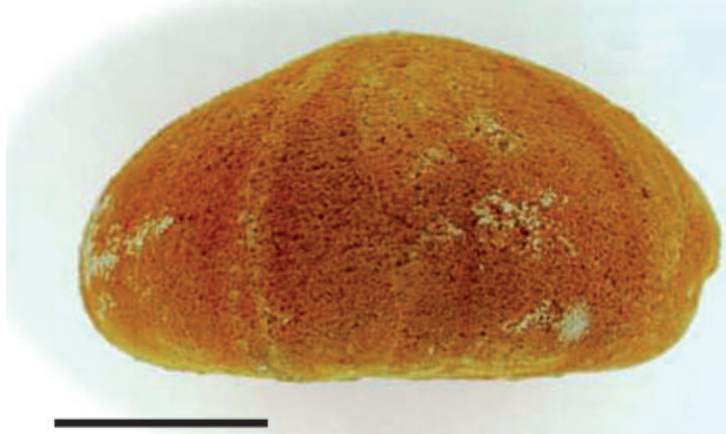

3

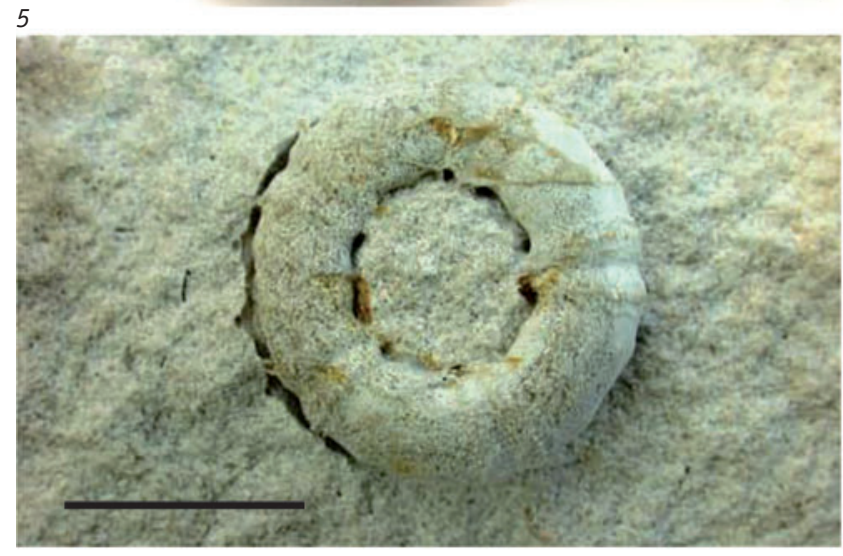

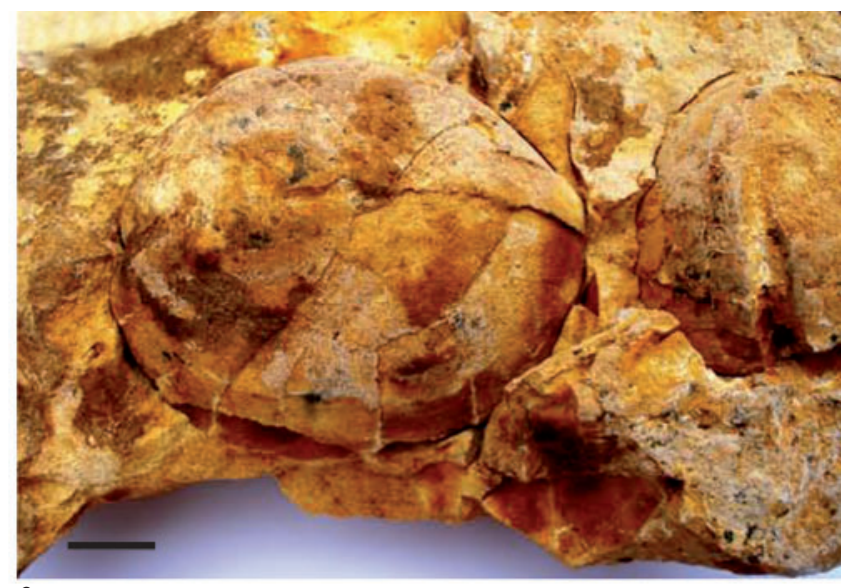

2
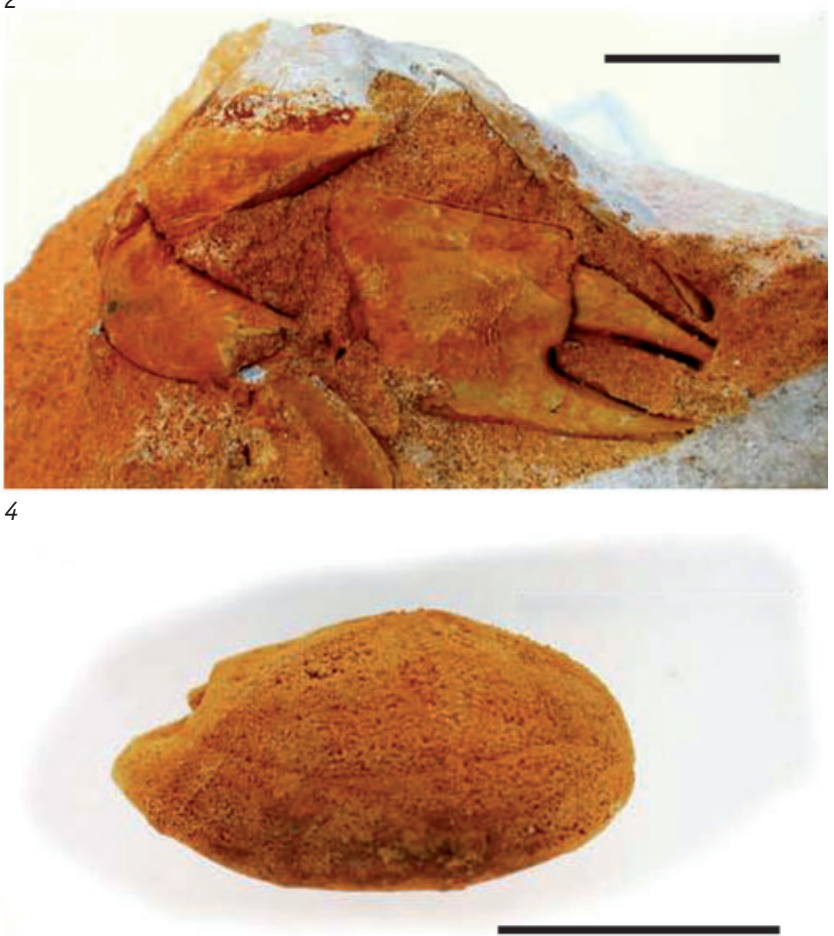

6

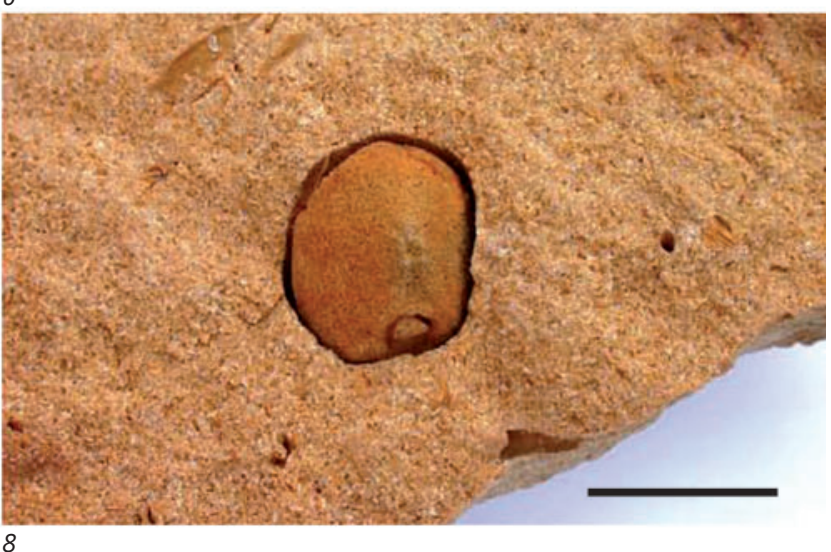

Fig. 14. Photographs of macrofossil taxa collected from 'Elst tauw' (GeoDoc 107W304). Scale bar 10 mm. 1. Leymeriaster eluvialis, apical view, co-occurring with Hemipneustes striatoradiatus, Rhyncholampas macari, bivalves and serpulids (R. Meuris Collection, RM 1991); 2. Hemipneustes striatoradiatus, original length $61 \mathrm{~mm}$, apical view of partially crushed specimen (P. Martens Collection, PM08a); 3. Oolopygus pyriformis, lateral view (L. Indeheberge Collection, LI 3a); 4. Protocallianassa faujasi (L. Indeherberge Collection, LI 04); 5. Rhyncholampas macari, oblique postero-lateral view (D. Geets Collection, DGE 01a); 6. Rhyncholampas macari, same specimen in lateral aspect; 7. Gauthieria radiata, oral view (G. Aerts Collection, GA 93L); 8. Procassidulus lapiscancri, apical view (R. Meuris Collection, RM 81a). 
presence of subangular detrital quartz grains (80-110 micrometre; Micrograph 17). Several chambers of the foraminifera are filled with pyrite-rich glauconite (Micrograph 20). Some larger agglomerates of (oxidised) pyrite are scattered throughout the groundmass. The bioclastic grainstone is only weakly cemented (Micrograph 21). The calcite cement consists of either limpid dog tooth spar, or of syntaxial overgrowths preferentially on echinoderm skeletal grains (crinoids, echinoids; Micrograph 18). Intraparticle pore filling occurs, mostly by dog tooth spar (Micrograph 22). The size of the pores ranges between 50 and 400 microns. A measurement of the macroporosity (pore size $>1$ micrometre) has been performed by means of $2 \mathrm{D}$-automated image analysis: it varies from 17.9 to 23.9 per cent in the samples studied. This is quite compatible with earlier measurements of the Roosburg facies (21.6 per cent) of the Maastricht Limestone (Dusar \& Dreesen, 2007).

The presence of pyrite, intraclasts, quartz and glauconite grains, remnants of micritic matrix and two phases of cementation are characteristic features for this deposit very near the base of the Maastricht Formation; they are considered as representative for the original fabric of the time- and depositional environment-equivalent strata near Elst.

\section{Discussion}

'Elst tauw' does not fit neatly in the models describing the formation of compact rocks in the Maastricht Formation. It has a stratigraphic position and a mode of formation quite unlike the 'tauw' layers, in casu hardgrounds or basal gravel horizons observed at quarries. Its location at the top of the remaining calcarenite deposit, below the dissolution residue contained in the Clay-with-flints and within a karstified surface, bears some resemblance to the mode of formation of 'heerd'. However, the silicified 'Elst tauw' occurs on the high ground in between the dolines and seems to predate their formation, whereas the calcitic 'heerd' surrounds the doline walls and seems to be contemporaneous to the formation of the dolines.

Another type of 'tauw' has already been studied in more detail. 'Tauw' from the underground quarries of Vechmaal, to the west of the Mergelland, originated as a partial silicification of the Kanne Horizon, located in the upper third of the Nekum Member. As such, the Kanne Horizon generally forms the roof for underground quarrying of Maastricht stone at Vechmaal. It is locally composed of a serpulid-turritellid bed. This type of 'tauw' is a light grey building stone showing a multitude of hollow tubes resulting from dissolution of the calcitic walls of the serpulids that resisted matrix silicification. By form and appearance and also by use in historical buildings, this type of 'tauw' resembles vesicular basalt. As historical building stone it is distributed over the south-central part of the ancient county of Loon, the natural hinterland for the products extracted from the Vechmaal quarries. Hence it has been called the Vechmaal facies (Dreesen et al., 2002; Dusar et al., 2005).
Secondary silicifications of chalk are not rare. East of the River Maas (Meuse), silicified chalk is associated with pedogenesis on Cenozoic peneplains, resulting in large blocks preserved as geological monuments.

Whitish silicified chalk with nodular appearance, known as 'chailles', get their high porosity by dissolution of the carbonate matrix inside the nodules which are rich in biogenic silica (Cayeux, 1929).

A peculiar type of silicification in originally flint-bearing chalk is exemplified by the Saint-Denis microbialite of Turonian age in the Mons Basin. This secondary silicification occurred in exposed strata during a sea level fall, accompanied by karstic dissolution features under vadose circumstances whose silicification was enhanced by microbial action (Baele, 2010). Thus, the environment was different from that of the 'Elst tauw', which was never exposed but originated under a Claywith-flints cover. However, oxidised pyrite led in both cases to orange-brown porous silicites.

Because of their mineralogical composition, building stones of silicified 'tauw' show some analogies with real flint (equivalent of chert) but lack the dark colour and the characteristic brittle, conchoidal cleavage. Some abnormally thick flint occurrences, in fact the merger of successive flint layers such as the $>2 \mathrm{~m}$ thick flint bed at the Wolfskop quarry near Cadier en Keer (southern Limburg, the Netherlands), were extremely hard to extract, requiring a specialised work force. However, their rock properties remained those of normal flint (Lijdsman, 1944; P.J. Felder, 2001).

'Elst tauw' is encountered immediately below the Clay-withflints ('Vuursteeneluvium'), the residue left after dissolution of the carbonates. Clay-with-flints is concentrated on the eroded top of the Cretaceous deposits and may find its way by mechanical reworking, through the overlying Quaternary loam into the ploughing zone. Eluvial fossil-rich beds preserve to a large extent their original geometrical relationship to the chalk/calcarenite sequences of which they are the remnants. This has been demonstrated at numerous localities, even at places where the original carbonate has been totally dissolved (Bless et al., 1991). Generally, they are dated by their microfauna (e.g., Quesnel et al., 1996, 2003), but in this particular case the macrofauna, particularly the echinoid portion, has been used for retracing the stratigraphic position of the original unweathered marine sediment. Successive flint layers occurring in the Hesbaye region and the St Pietersberg (Montagne St.-Pierre) can be compared to the palaeontological succession on the large, permanently accessible quarries/ outcrops, which serve as reference sections (Van der Ham et al., 2006). Temporary excavations present additional opportunities to collect fossils (Indeherberge et al., 1993, 1996). Among the discoloured eluvial flint, all flint blocks presenting dissolved fossils and hollows are casually referred to as 'tauw' but most do not present its typical mechanical characteristic: 'tauw' is chiselled, flint is cleaved. 
Micrographs of 'Elst tauw' (silicified limestone and nodular flint)

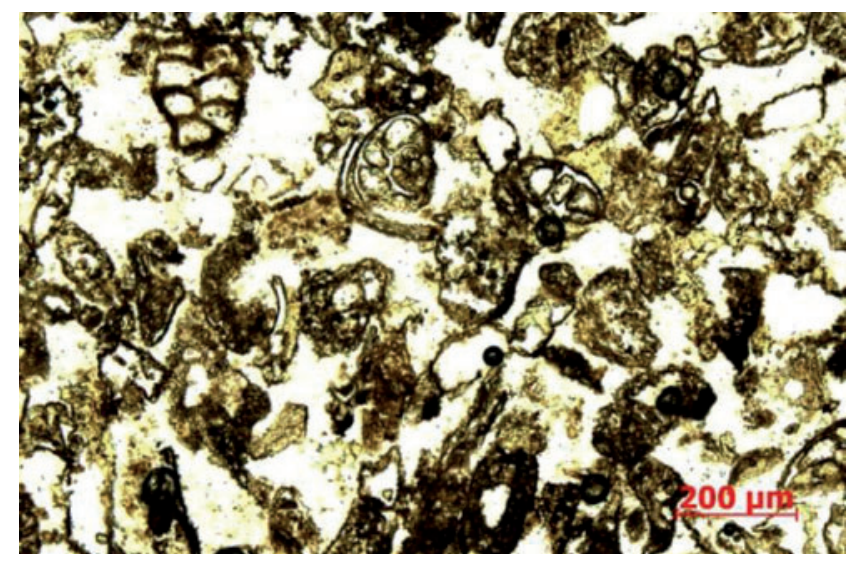

1. Micrograph of silicified limestone (GeoDoc 107W304; Fig. 6): bioclastic grainstone where the contours of the former calcareous skeletal grains are still visible because of a surperficial impregnation by limonite. Skeletal fragments of plurilocular foraminifera and of echinoderms can be recognised. Transmitted polarised light.

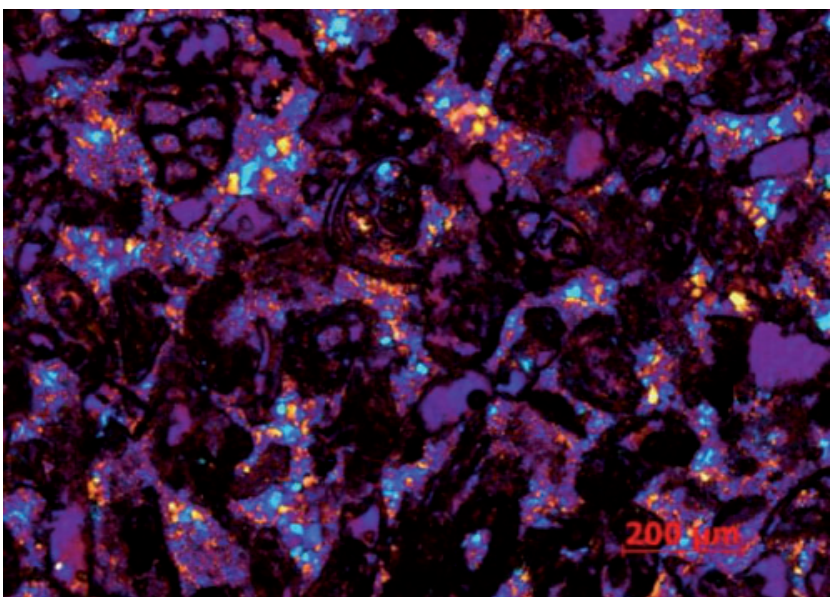

3. Same image but taken with crossed polars and gypsum plate. The even purple-coloured spots are pores = dissolved skeletal grains (mouldic porosity).

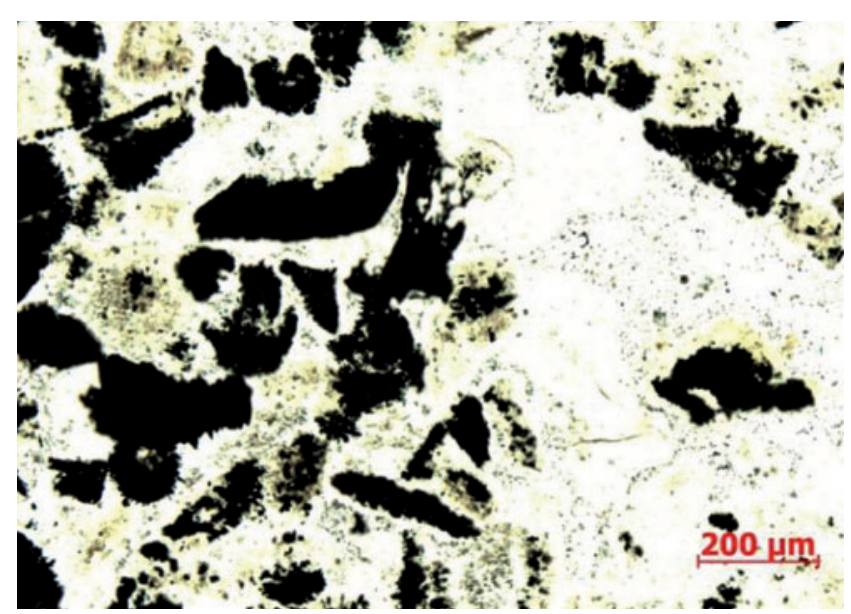

5. Detail of a dense silicified area (flint nodule) within the silicified limestone (sample 107W304; Fig. 5). Large transparent (limpid) zones of microsilica with 'floating' skeletal grains that are pyritised (opaque = black). Transmitted polarised light.

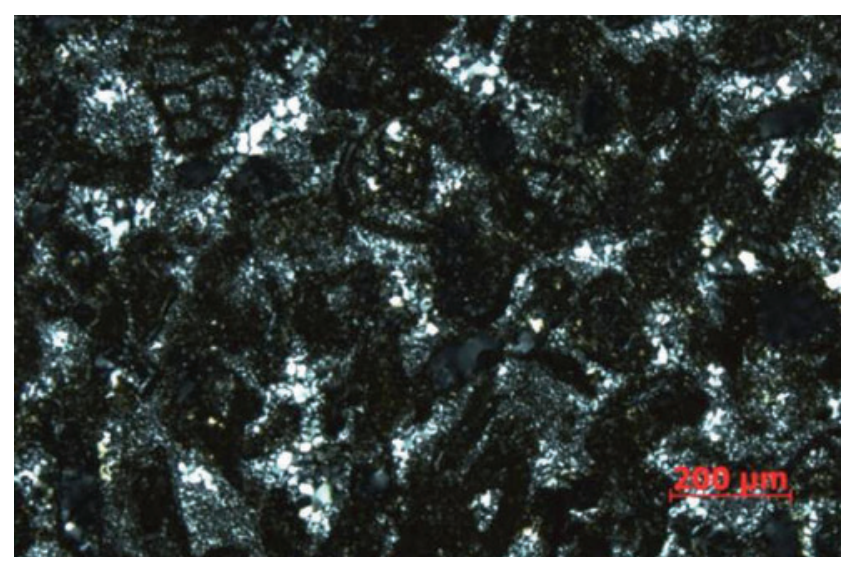

2. Same image taken with crossed polars. The silica cement is dominated by microcrystalline quartz (microquartz) and megaquartz. Dark-grey oval spots are secondary (mouldic) pores $=$ dissolved, partially limonitised skeletal grains.

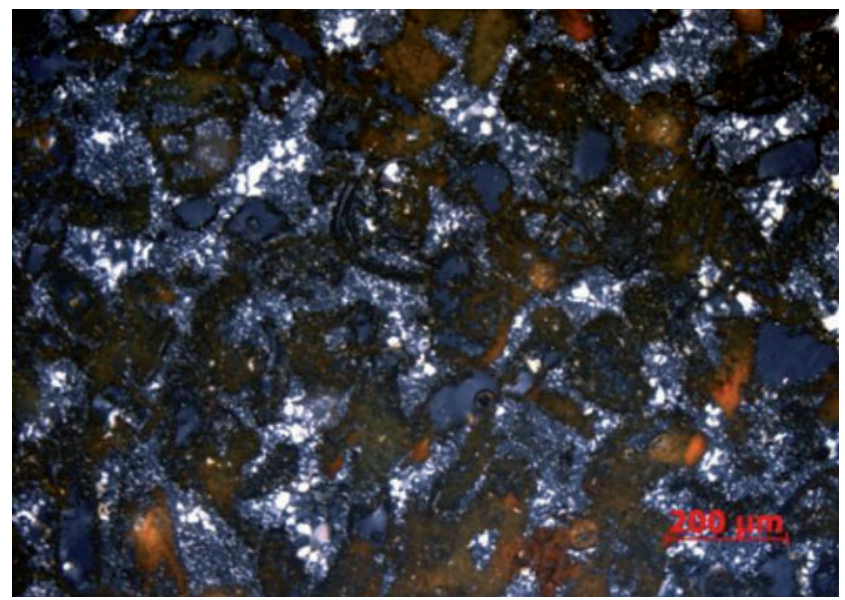

4. Same image taken in incident light, highlighting the limonitised skeletal grains (red-brown staining).

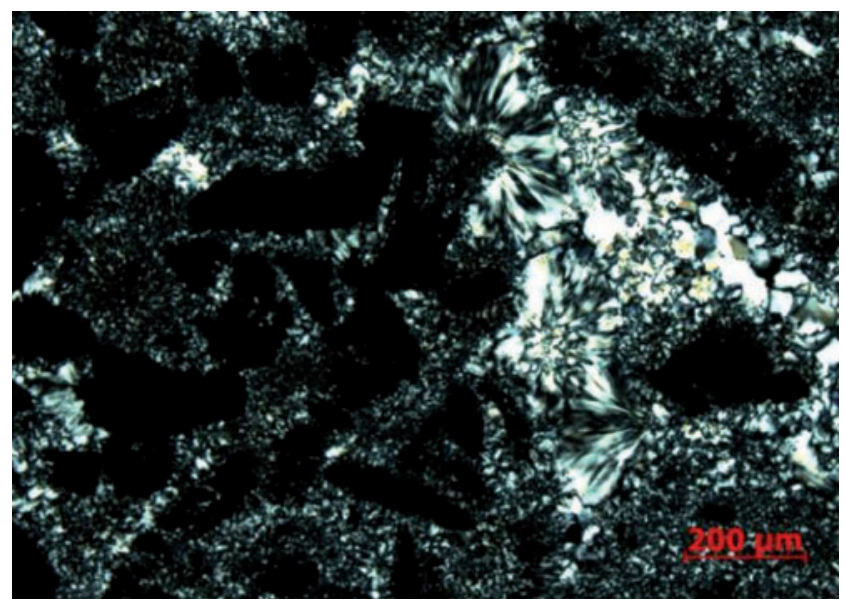

6. Same image but taken with crossed polars. In the interparticle silica cement, microcrystalline quartz (dominant) and fibrous chalcedony are present. The large pore is preferentially filled with chalcedony and megaquartz. 


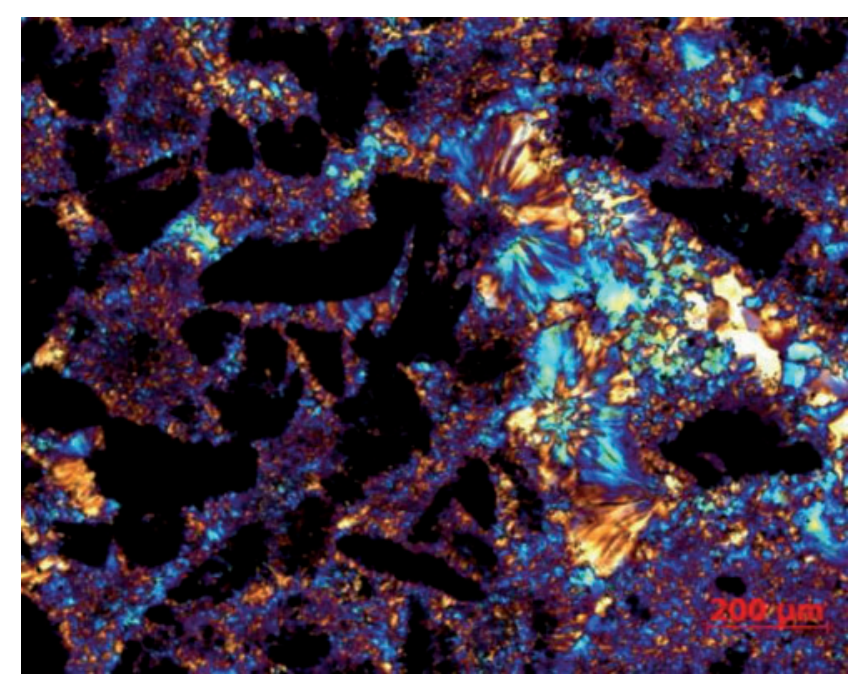

7. Same image, with crossed nicols and gypsum plate.

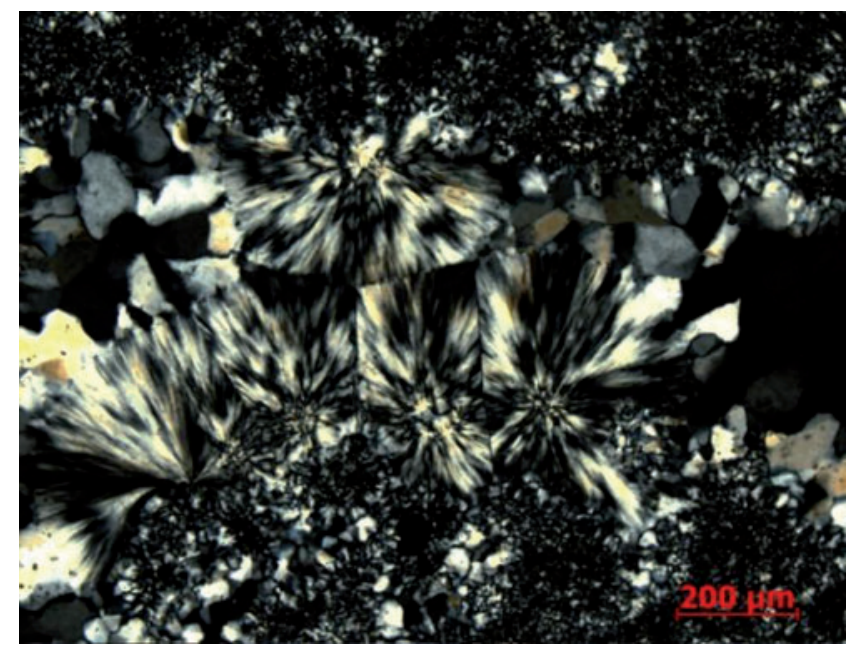

9. Detail of a large intraparticle pore from GeoDoc 107 W304 (Fig. 5, flint) filled with chalcedony and megaquartz. Transmitted polarised light.

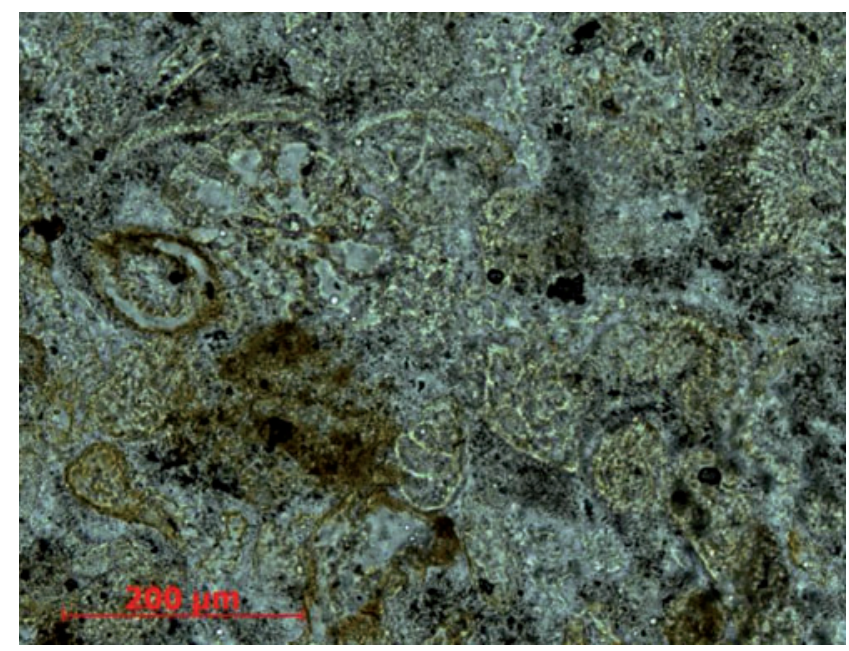

11. Detail of the silicified limestone (RBINS building stone collection 222; see Fig. 9) with 'ghosts' of skeletal grains (bioclasts), the contours of which are accentuated by limonite impregnation (lining). Plurilocular foraminifera can be recognised. Transmitted polarised light.

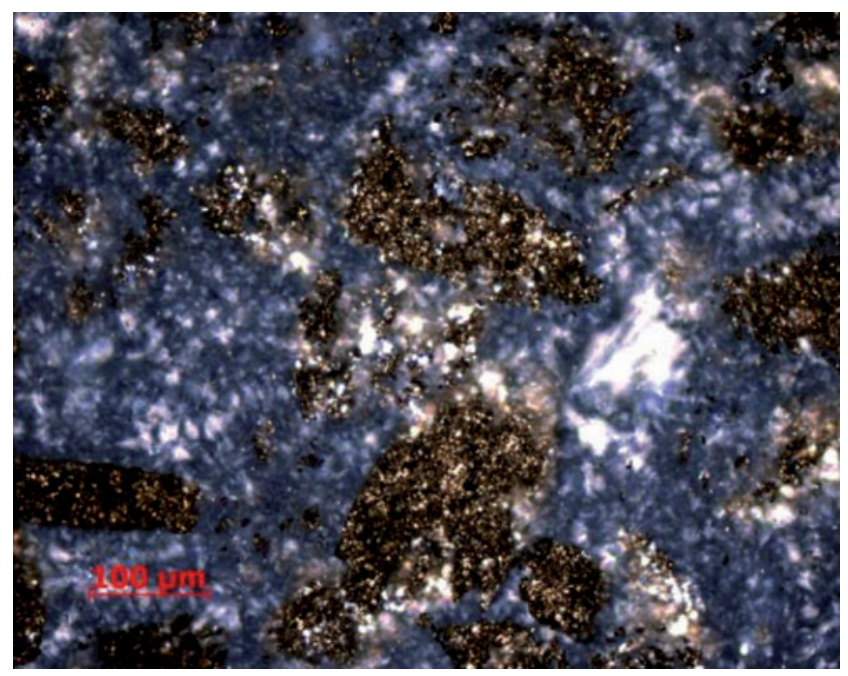

8. Detail of micrograph 5, taken in transmitted polarised light. The opaque allochems consist all of golden yellow pyrite crystals.

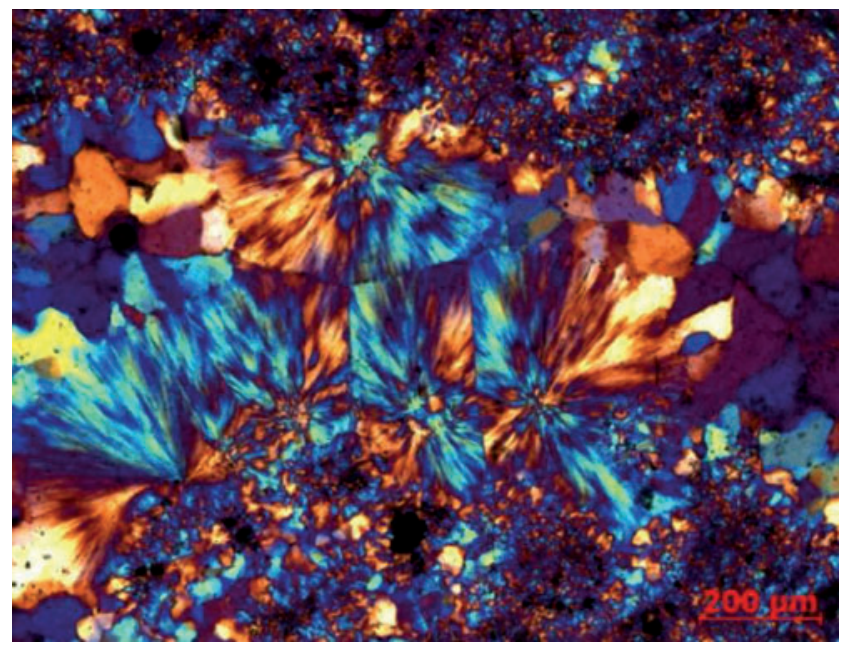

10. Same image, taken with crossed polars and gypsum plate.

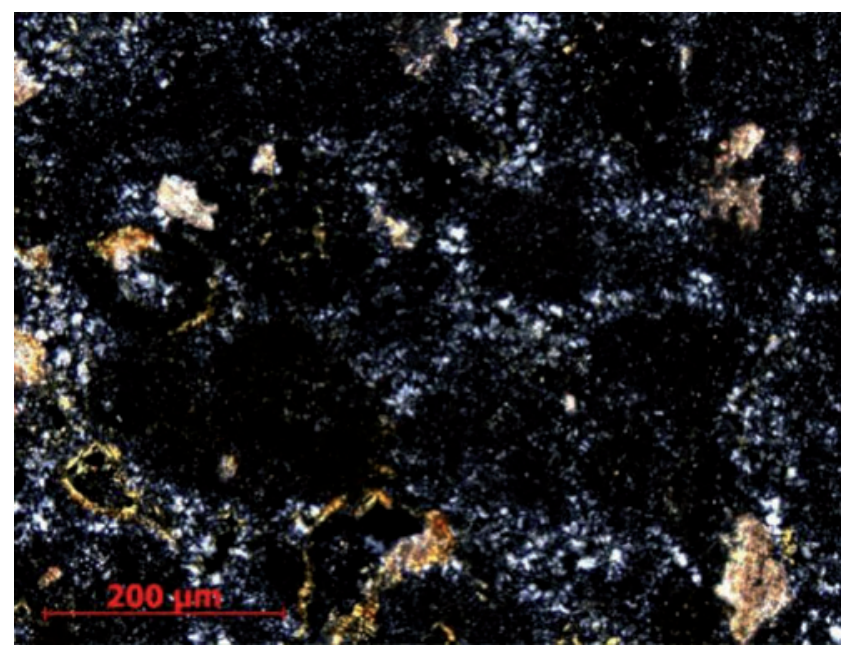

12. Same image, with crossed polars. The relics of calcite in the limonitised allochems are obvious. The silica cement consists mainly of recrystallised microquartz, now megaquartz. 


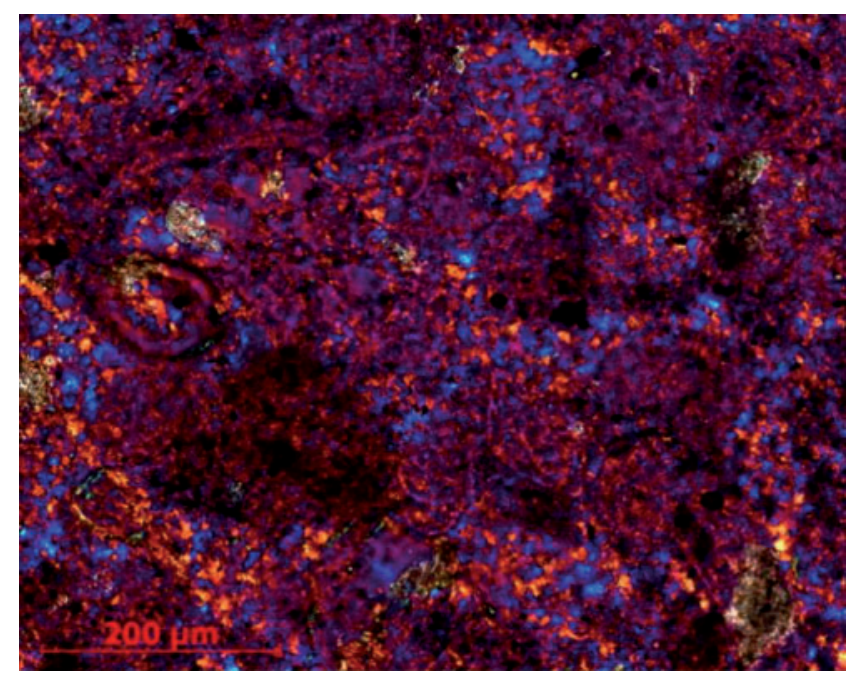

13. Same image taken with crossed polars and gypsum plate.

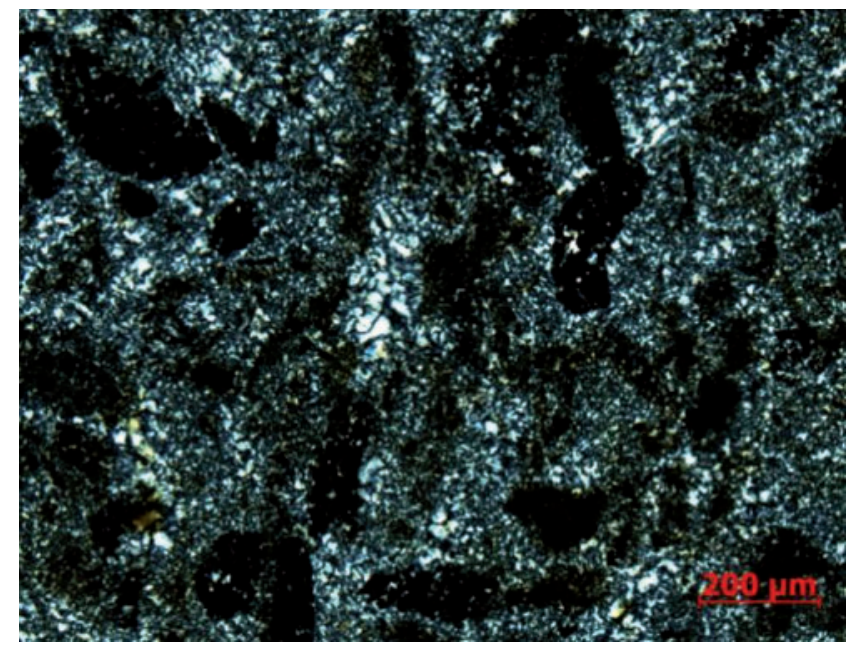

15. Same image, taken with crossed polars. The silica cement contains microcrystalline quartz, chalcedony and megaquartz.

In the Maurissen pit at Elst, the calcarenitic sediment underlying the 'tauw' layer that would represent the original sediment prior to silicification, could not be studied petrographically. The best exposure of time-equivalent sediments is located in the Roosburg underground quarry at Zichen, about $5 \mathrm{~km}$ east of Elst (Fig. 1). The Roosburg quarry furnished the best-quality Maastricht building stone. Bioclast analysis by the late P.J. Felder combined with lithological correlation by the late W.M. Felder confirmed that the quarried strata are older than any other known Maastricht building stone type. They are assigned to the Valkenburg to Gronsveld members of the Maastricht Formation, the same age range as inferred for the original sediment of the 'Elst tauw' (P.J. Felder \& W.M. Felder, 2008). Comparison of the carbonate microfacies and mineralogical content of the 'tauw' samples with those taken from the calcarenite of the Roosburg quarry, allows to confirm their

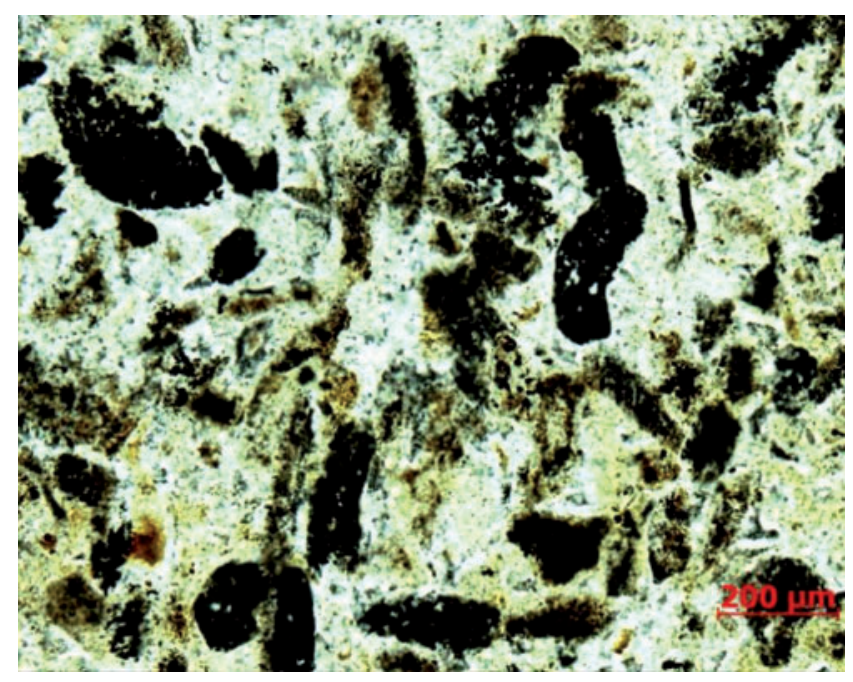

14. Detail of a strongly silicified and hence denser zone (flint) within the silicified limestone (same building stone collection sample 222; see Fig. 10). Almost completely pyritised skeletal grains 'float' in a transparent (limpid) silica matrix. Transmitted polarised light.

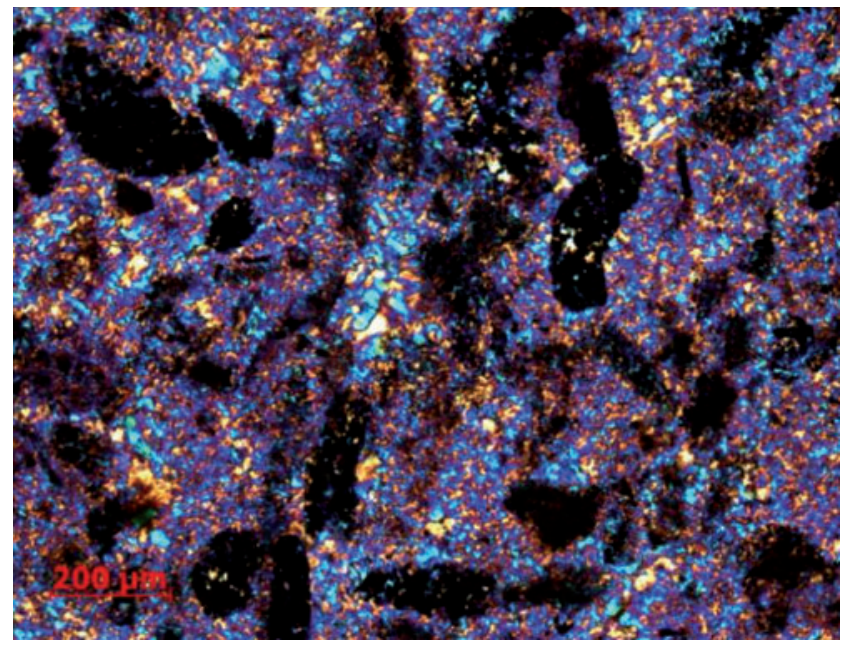

16. Same image, taken with crossed polars and gypsum plate. The large pore is occupied by fibrous chalcedony and megaquartz.

lithostratigraphical equivalency. Particularly, the early micritisation and pyritisation of the bioclasts is a characteristic feature affecting these sediments, which subsequently might have enhanced the dissolution and replacement of the carbonate sediment.

Petrographical analysis of thin sections and scanning electron analysis of 'tauw' from the Maurissen sand pit and from building stones have elucidated their complex diagenetic history, while confirming their common origin. Successive phases of pyritisation, silica cementation, oxidation and dissolution have led to the formation of this particular porous silicified limestone.

The diagenetic sequence leading to the 'Elst tauw' is particular. Its silicification in a carbonate environment must have had a catalyst, pyrite, and a trigger, changing redox conditions (Carozzi, 1960, 1993; Clayton, 1986; Knauth, 1994). Pyritisation due to 
Micrographs of Roosburg block (calcarenitic limestone)

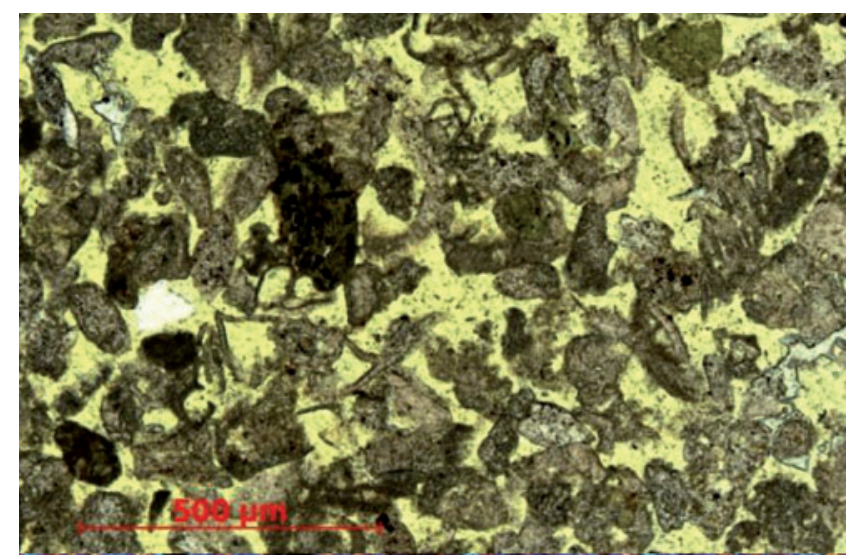

17. Micrograph of Maastricht limestone (Roosburg). General overview of the bioclastic grainstone. Note presence of a few dispersed dark-green to brown glauconite grains and of a few angular detrital quartz grains. Transmitted polarised light.

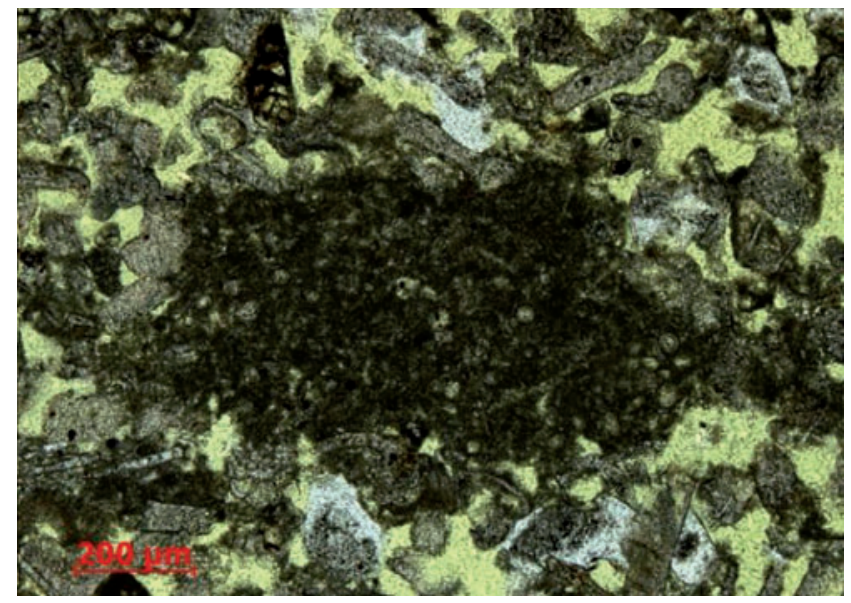

19. Detail of a fine-grained intraclast consisting of a foraminiferal wackestone (chalk?). Transmitted polarised light.

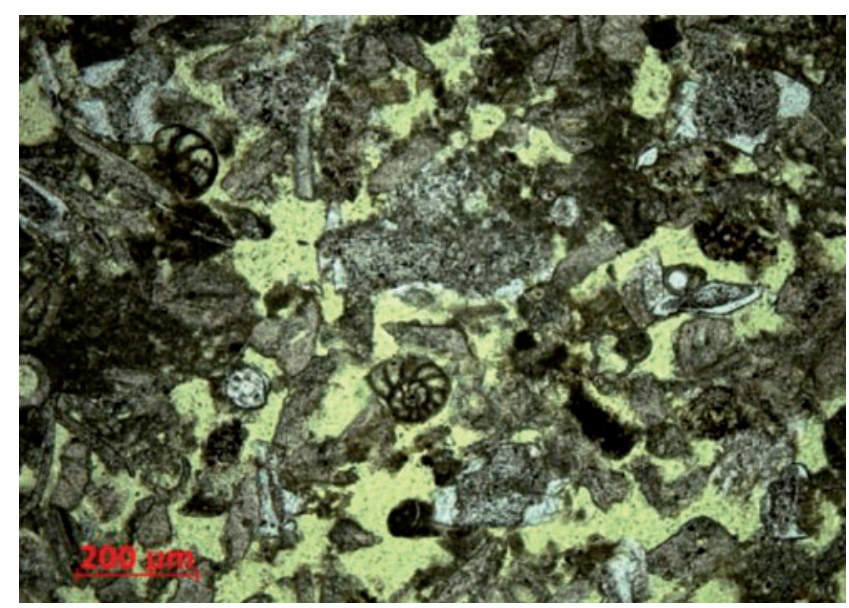

21. Micrograph of the same sample. General overview of porous grainstone texture and lack of important cementation. Note presence of limpid calcite cement ( = syntaxial calcite overgrowths) on echinoderm bioclasts. Transmitted polarised light.

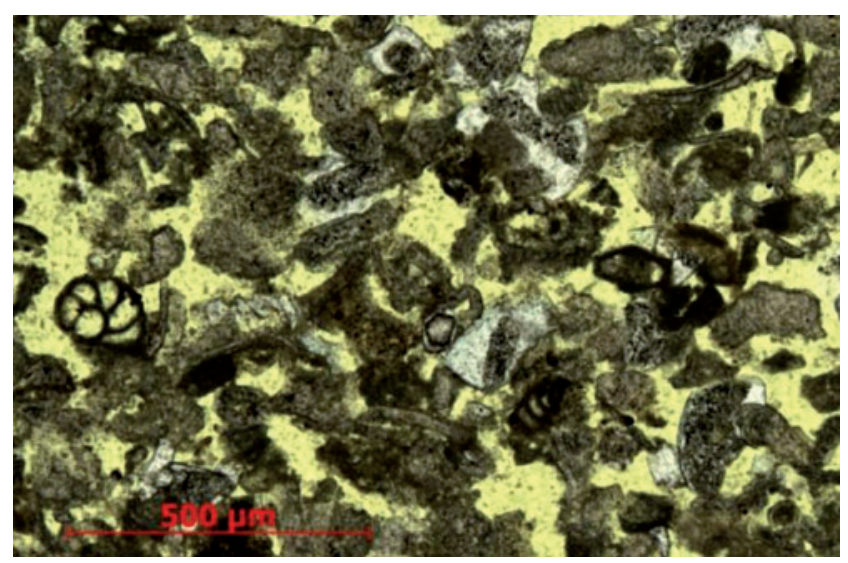

18. Micrograph of the same sample. Note plurilocular forams and presence of limpid sparite cement (syntaxial overgrowths on echinoderm skeletal grains). Transmitted polarised light.

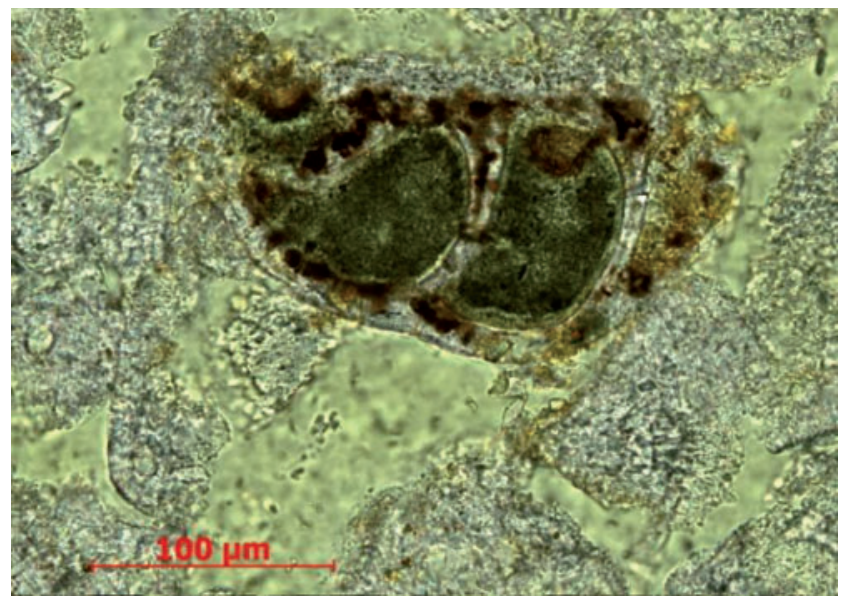

20. Detail of a skeletal grain (fragment of a plurilocular foraminifer) the chambers of which are filled with glauconite. Note also presence of brown oxidised pyrite in the shell. Transmitted polarised light.

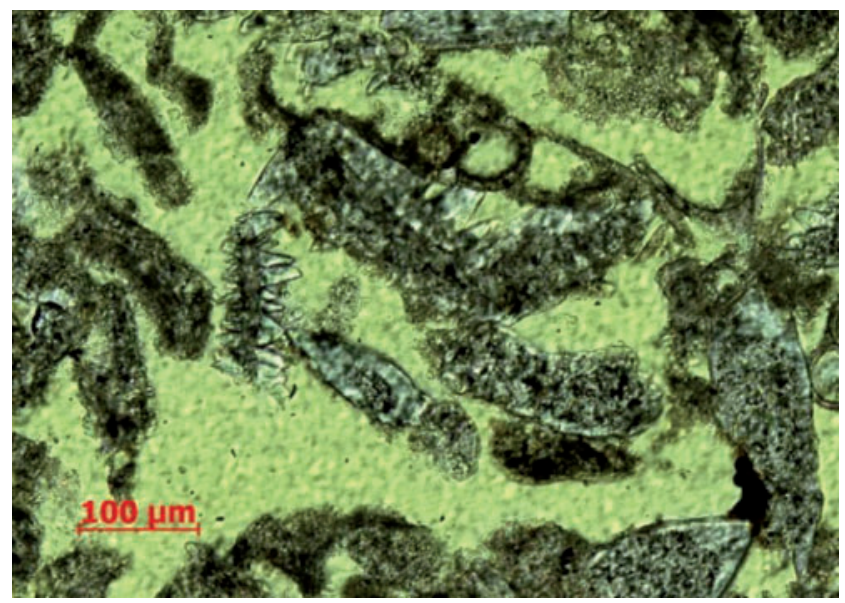

22. Detail of dog tooth spar cement growing on skeletal grains. Transmitted polarised light. 


\section{SEM images}

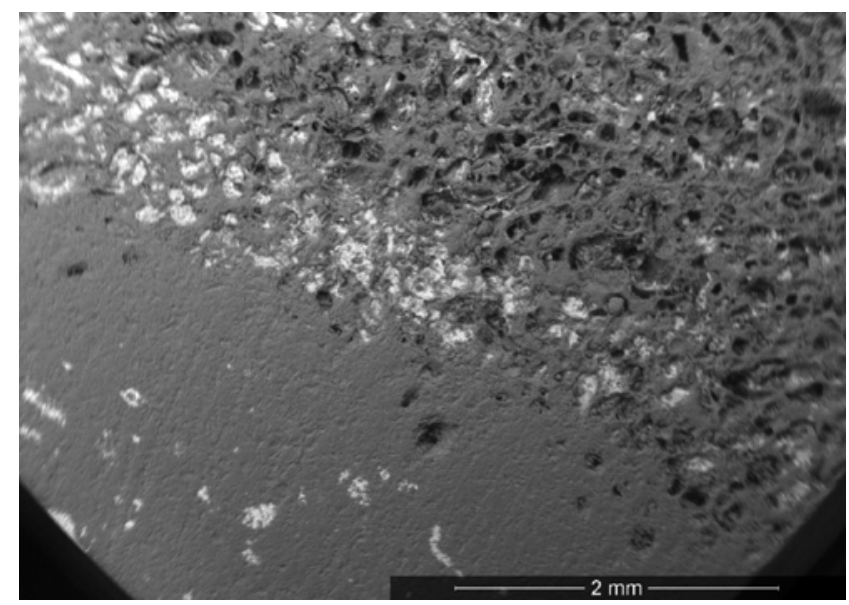

23. 'Elst tauw' (GeoDoc 107W304). Overview from flint nodule with pyritised allochems (seen as isolated white spots), over oxidized rim with iron oxide impregnations (seen as concentration of white spots) to 'tauw' sensu stricto marked by mouldic pores and some stringers with iron oxide impregnation.

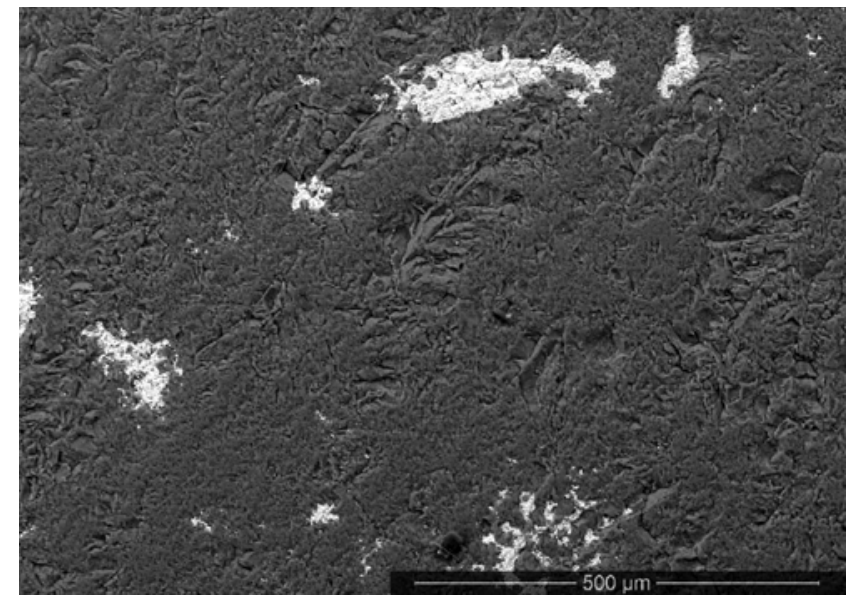

25. 'Elst tauw' (GeoDoc 107W304). Flint nodule composed of microcrystalline quartz alternating with chalcedony bundles, containing dispersed pyritised allochems.

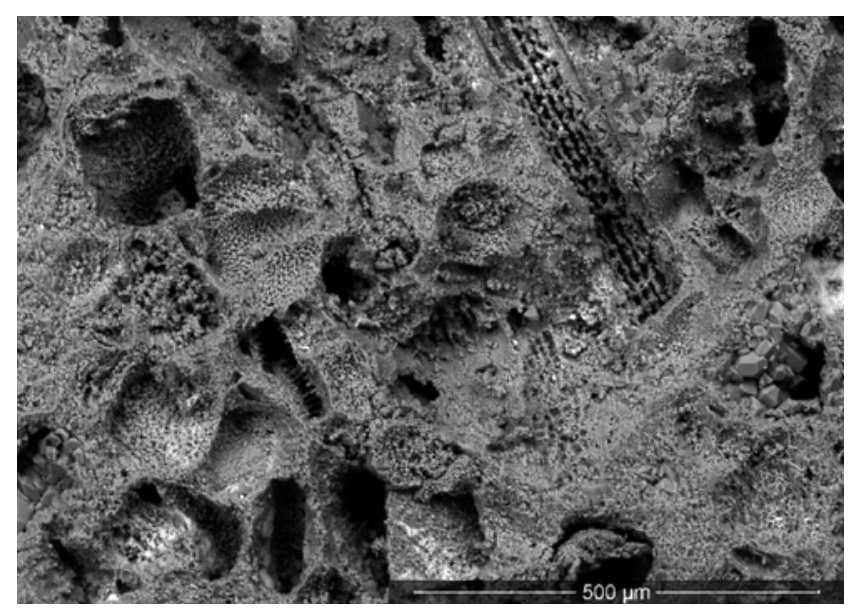

27. 'Elst tauw' (GeoDoc 107W304). Microcrystalline to cryptocrystalline quartz with moulds left by dissolved bioclasts (abundant foraminifera are recognisable as well as some echinoderm remains).

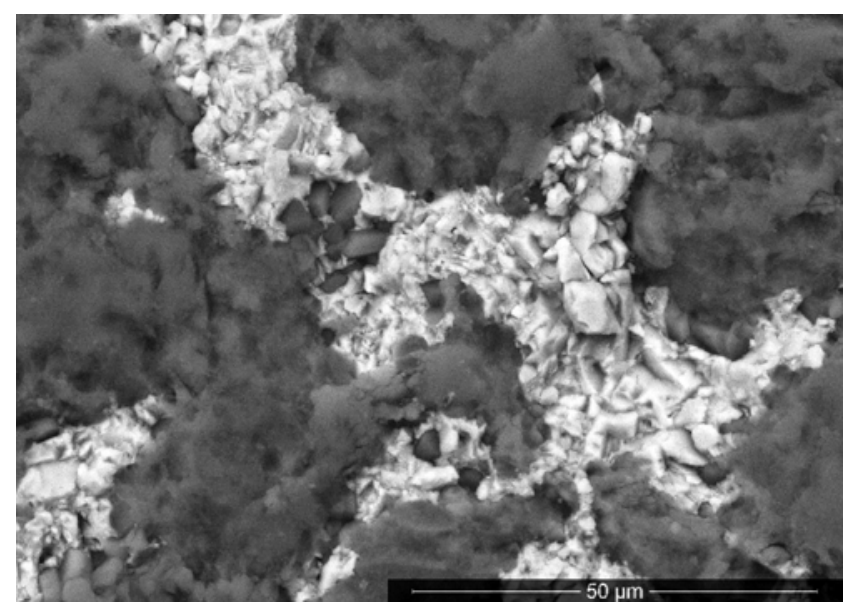

24. 'Elst tauw' (GeoDoc 107W304). Crystalline pyrite of different sizes impregnating outline of echinoderm (?, at bottom of photo 25) embedded in microcrystalline quartz of flint nodule.

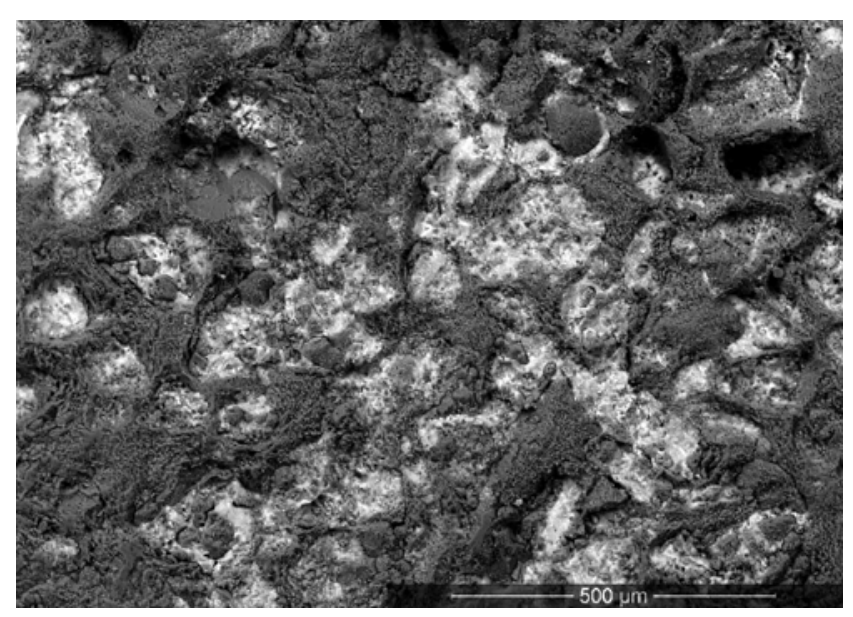

26. 'Elst tauw (GeoDoc 107W304). Microcrystalline quartz with moulds after dissolved allochems impregnated with iron oxide (goethite) aggregates.

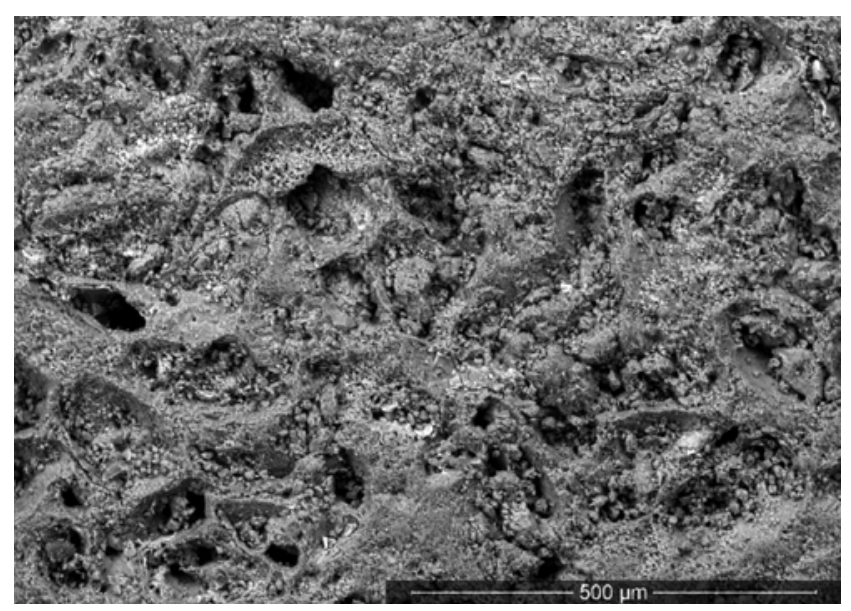

28. 'Elst tauw' (RBINS building stone collection 222). Microcrystalline to cryptocrystalline quartz with moulds after dissolved bioclasts, dusted by microcrystalline quartz. 


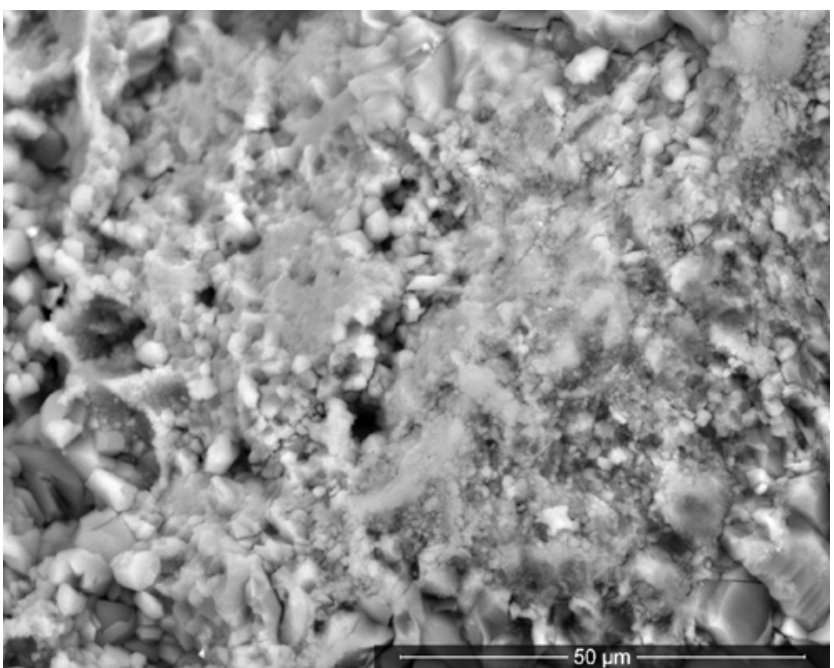

29. 'Elst tauw' (GeoDoc 107W304). Matrix composed of interlaced cryptocrystalline quartz, microcrystalline quartz and larger quartz crystals filling pore spaces.

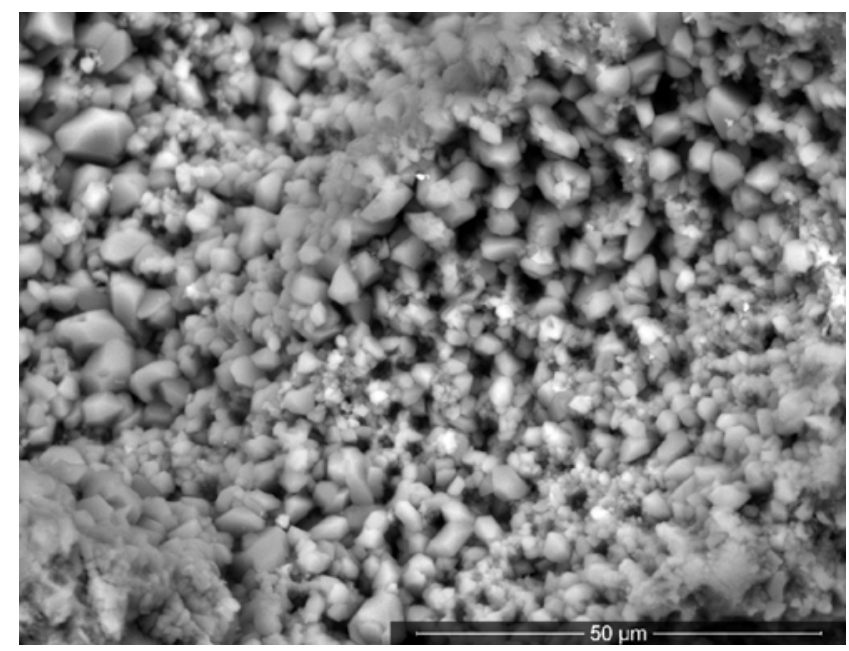

31. 'Elst tauw' (GeoDoc 107W304). Equigranular microcrystalline quartz lining the wall of a dissolved foraminifer chamber.

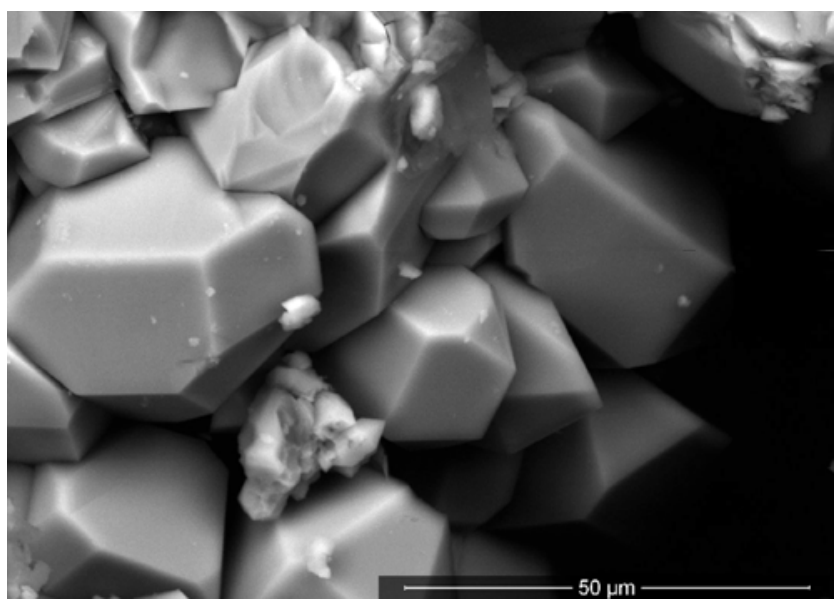

33. 'Elst tauw' (GeoDoc 107W304; Maurissen sand pit). Regular quartz crystals as overgrowth of microcrystalline quartz (displaced remnant in lower left) in mouldic pore. Conchoidal fractures in upper part are due to cutting with diamond saw.

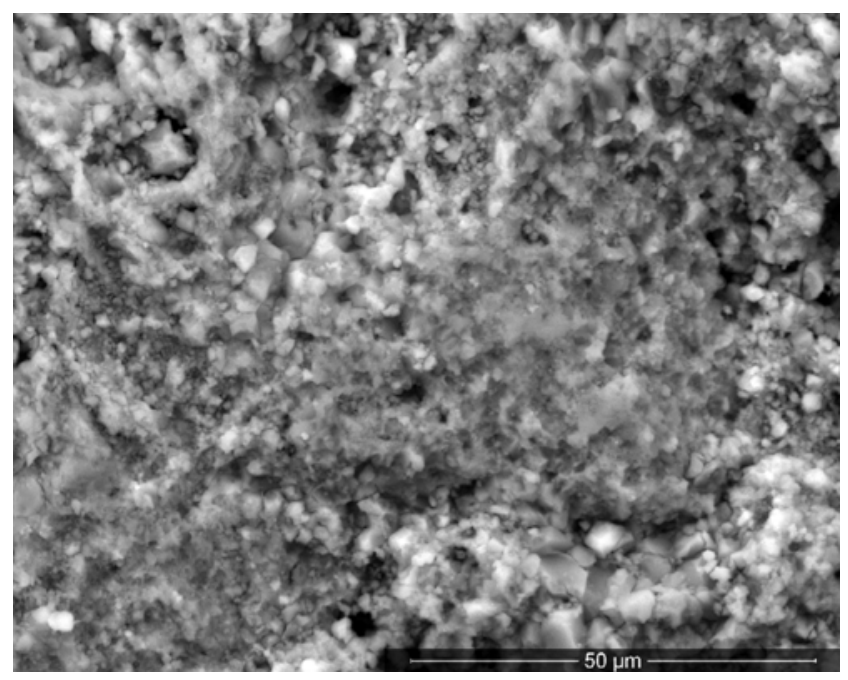

30. 'Elst tauw' (RBINS building stone collection 222). Matrix showing identical build as 'tauw' from natural occurrence (see SEM image 29).

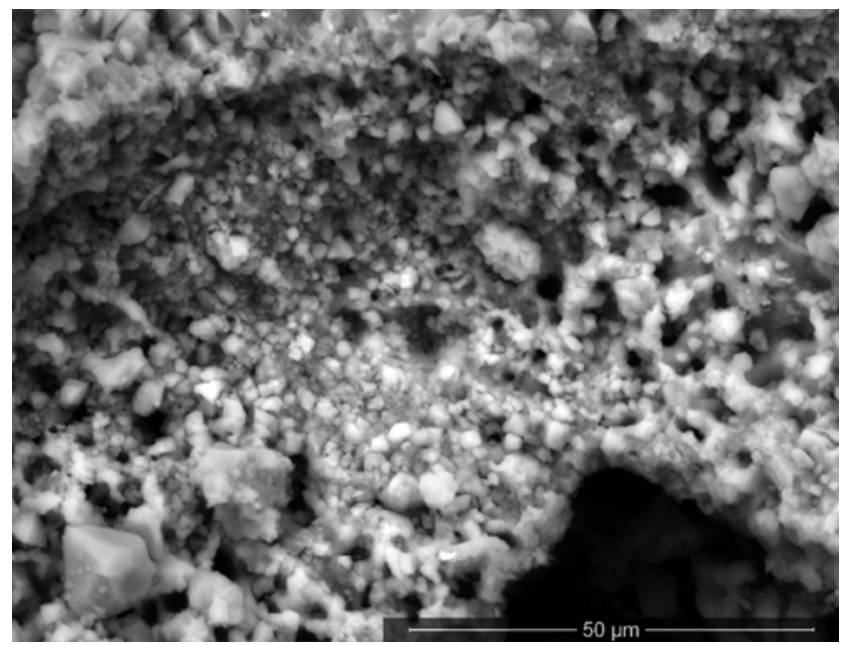

32. 'Elst tauw' (RBINS building stone collection 222). Irregular microcrystalline quartz assembly bordering mouldic pore.

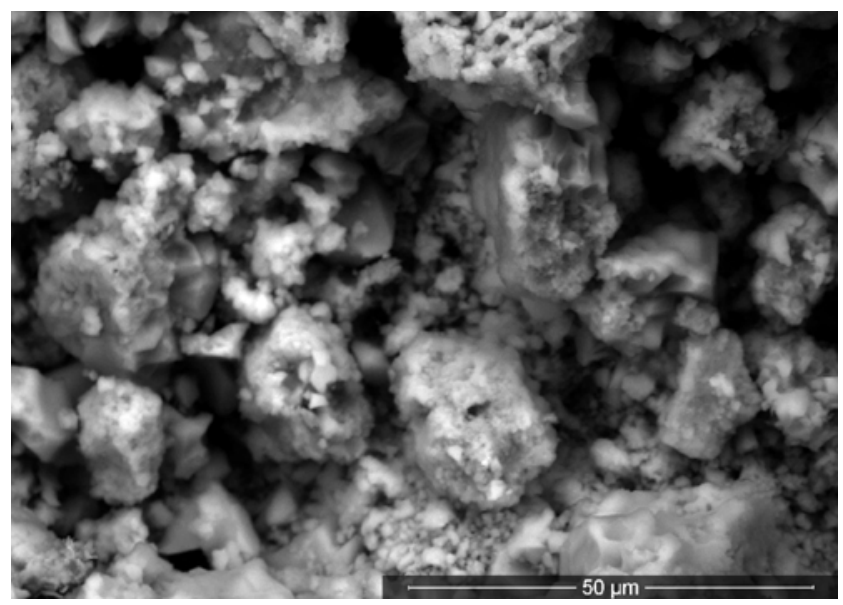

34. 'Elst tauw' (RBINS building stone collection 222; St Servatius church, Sluizen). Etched quartz crystals as overgrowth of microcrystalline quartz. 
sulphate reduction of calcareous particles in calcarenite and flint is the first step towards silicification, which must have occurred prior to complete lithification of the flint nodules. The next diagenetic stages must have occurred in a terrestrial environment, after deep erosion and coverage by the Clay-withflints residual deposit, in a rather short time span. 0xidising fluids migrating into the porous anaerobic zone of the Cretaceous, underneath the overburden, could liberate $\mathrm{H}_{2} \mathrm{~S}$ from the pyrite. Pyrite is currently preserved only in the impervious flint nodules, but must have been equally present in the calcarenite. Re-oxidation of $\mathrm{H}_{2} \mathrm{~S}$ to sulphate liberated $\mathrm{H}^{+}$ions at the oxic-anoxic boundary, probably corresponding to the border with the Clay-with-flints, reducing local $\mathrm{pH}$ causing calcite dissolution, saturating solutions and chemical seeding of dissolved silica. Calcite dissolution and silica precipitation occurred nearly simultaneously, so that the original fabric was preserved (Fig. 11). The source of silica could not be found in the Cretaceous, where Si remained largely immobilised in the flint nodules (with exception of the outer weathering rim, insufficient by volume), but must have come from overlying, superficial strata. During the Cenozoic, continental weathering and pedogenesis could have provided concentration of organic matter initiating the sulphate reduction conditions, and hence liberating the silica. This silicification process was concentrated in more porous zones, underneath a more clayey overburden. The Clay-with-flints created a relative permeability barrier; the dissolution and silicification event would thus affect the topmost permeable layer of the underlying calcarenite.

The Cenozoic could have provided ample opportunity for these diagenetic events to occur. The post-Maastrichtian environment varied from marine karstic mixed-water conditions (around the K/Pg boundary; see Swennen \& Dusar, 1997), lacustrine conditions with peat beds (during the Selandian), uplift area conditions (during the remaining Paleocene and Eocene), marine transgressions interrupted by lacustrine conditions (during the Oligocene and Early Miocene), and renewed uplift conditions with weathering and faulting, also affecting the Oligocene deposits (during the Miocene-Pliocene).

Timing of the diagenetic events affecting the transformation of original bioclastic fossiliferous calcarenite into 'tauw' likely was between the latest Maastrichtian and Early Oligocene. These events occurred all under shallow burial and meteoric or mixing zone conditions, after dissolution of the major part of the Maastricht Formation and formation of the Clay-with-flints. Coverage by the Oligocene sands may have inhibited large-scale dissolution of the underlying carbonates, as these slightly clayey sands do not seem to be affected by enhanced weathering, beyond the oxidation associated with their position above the water table. The sealing effect of the Oligocene sands on the underlying calcarenites is demonstrated by the negative correlation with (younger) karstic features (epikarstic dolines, caves, vertical 'earth pipes') compared to the frequent occurrence of these features in the top of the calcarenite underneath River
Maas (Meuse) gravels, as observed in the Romontbos quarry at Eben Emael (Juvigné, 1992). Further to the west on the Hesbaye Plateau, the Clay-with-flints deposit is sealed by Selandian marls and/or Thanetian clays, restricting their age even further. At many sites, however, dissolution resumed after erosion of this impervious and calcareous cover during the Neogene, before renewed sealing under Pleistocene loesses.

The proposed scenario contradicts the association of the Clay-with-flints deposit with deep Miocene-Pliocene weathering and peneplanation (W.M. Felder \& Bosch, 2000), at least at this particular site where the Clay-with-flints is overlain by Oligocene sands and underlain by 'tauw'.

Although the stratigraphic position and petrographical composition of the 'Elst tauw' could be elucidated and the correspondence between the building stone and the natural occurrence has been sufficiently demonstrated, one question still remains: from where did the building stones used in Sluizen and Vreren originate? The natural occurrence of the 'Elst tauw' at the bottom of a deep sand pit cannot have provided building stones for the churches in Sluizen and Vreren. No other 'tauw' exposures are known from the Jeker River valley and it must be assumed that this peculiar type of 'tauw' has a restricted geographical extension. The most likely places where this type of 'tauw' must once have been exposed, following the intersection between strike and topography, is within the Jeker River valley north of Sluizen, in the direction of the village of Mal. Here, earlier quarrying has left many traces in the landscape but Cretaceous beds no longer outcrop. This area occurs in between the historical monuments in which 'Elst tauw' has been used and thus represents the most plausible location.

\section{Conclusions}

'Tauw' is the vernacular name of a peculiar silica-rich rock type, different from flint, that is typical of the Maastricht Formation in the Mergelland area. However, 'tauw' has been defined according to different criteria by quarrymen, stratigraphers and scholars of our architectural heritage.

The present petrographical-palaeontological study improves our knowledge of the architectural heritage and of the regional geological history of the Mergelland. The co-operation between geologists and amateur palaeontologists has resulted in elucidating the origin of a particular building stone subspecies of 'tauw', used in Romanesque village churches in the Jeker River valley. This has been achieved by identifying the same rock type in situ in the Maurissen sand pit at Elst on the Hesbaye Plateau, hence the name 'Elst tauw' given to this stone species. Here, the 'tauw' layer was temporarily exposed at the top of Maastricht limestone, underneath the Clay-with-flints ('vuursteeneluvium') and Oligocene sands. Its stratigraphic position in the Cretaceous sequence could be determined by macrofossils, mainly exceptionally rich echinoid faunas. The 
fauna collected in the flint eluvium and 'tauw' layer at Elst is outstanding among collections derived from flint eluvium deposits in the Liège-Belgian Limburg border area, because it covers a stratigraphical range from the Lanaye Member (Gulpen Formation) through the Emael-Nekum members (Maastricht Formation), rarely sampled elsewhere. The silicified deposits on top of the Cretaceous in the Maurissen sand pit are stratigraphically equivalent to the Valkenburg-GronsveldSchiepersberg members, representing a condensed interval of the lower Maastricht Formation in the Jeker River valley region. So far as can be judged, there is great similarity in biofacies between the non-silicified calcarenitic deposit of the Roosburg quarry (Roosburg block variety of Maastricht stone) and the original carbonate sediment of the now silicified 'Elst tauw', which are both assigned to the same lithostratigraphical interval.

'Elst-type tauw' is rare in the Mergelland area. Therefore, two questions arise: what mechanism triggered this peculiar secondary silicification and why is it only known in one particular area?

The key is probably to be found in the pyrite, largely available as pyritised clasts at the base of the Maastricht Formation in the region studied. Deep weathering and dissolution of carbonate brought this stratigraphic level near the top of the Cretaceous section, but kept it buried under a Clay-with-flints deposit, itself covered by soils. Redox changes in the permeable top Cretaceous oxidised the pyritised clasts (leaving iron oxides aggregating at the oxidation fronts around flint nodules and colouring the rock), mobilising silica from the soil to be deposited as cryptocrystalline quartz to megaquartz in the pore space and replacing pyritised allochems of the calcarenite, prior to dissolution of the remaining carbonate allochems, thereby reversing the original fabric.

The potential extension of the 'Elst tauw' deposit is restricted to the small subcrop zone of $<10 \mathrm{~m}$ of basal strata of the Maastricht Formation, possessing the right pyrite-rich calcarenite facies. Hence it is not abnormal that 'Elst tauw' has only been used as a building stone where this horizon cropped out, at its intersection with the Jeker River valley, within less than $1 \mathrm{~km}$ from the Maurissen sand pit.

\section{Acknowledgements}

We thank the late J. Nijssen (St.-Martens-Voeren), valued member of the Geology Working Group of LIKONA (Limburg Co-ordination Centre for Nature Research) for his research on the etymological origin of 'tauw'. Architects Maria Leus and Jan Posen (PHL University College of Arts and Architecture, University of Hasselt) were intrigued by the peculiar building stones used in the St Servatius church at Sluizen during the last restauration campaign but could not obtain a clear explanation at that time. Ton Breuls (Studiegroep 0ndergrondse Kalksteengroeven, SOK) was an instructive guide through the
Roosburg underground quarry, allowing comparison between the silicified 'tauw' facies and the calcarenitic building stone facies. David Lagrou (VIT0) was a partner in the elucidation of the quite intricate lithostratigraphic scheme of the Chalk Group in northern Belgium. Herman Goethals (RBINS) assisted with the scanning electron microscope analysis. Florence Quesnel (BRGM, Orléans) and Wim Dubelaar (TNO Bouw en Ondergrond/Geological Survey of the Netherlands, Utrecht) are thanked for their willingness to review this unusual paper and for constructive criticism. All members of the Working Group Krijt \& Vuursteeneluvium participated in the monitoring and sampling of 220 recorded fossil collecting sites in the Claywith-flints of the Liège-Belgian Limburg border area. They all contributed to our increased expertise in distinguishing materials from different flint beds, their mechanical behaviour and in silicone casting and taxonomic interpretation of fossil finds.

\section{References}

Baele, J.-M., 2010. Mode de formation de la roche silicifiée à bactéries fossiles du Crétacé supérieur du Bassin de Mons (microbialite de Saint-Denis). Académie royale de Belgique, Mémoires de la Classe des Sciences (3)12:1-131.

Bless, M.J.M., Demoulin, A., Felder, P.J., Jagt, J.W.M. \& Reynders, J.P.H., 1991. The Hautes Fagnes area (NE Belgium) as a monadnock during the Late Cretaceous. Annales de la Société géologique de Belgique 113 (1990): 75-101.

Bosch, P.W., 1989. Voorkomen en gebruik van natuurlijke bouwsteen in Limburg. Grondboor en Hamer 43: 215-222.

Carozzi, A.V., 1960. Microscopic sedimentary petrography. John Wiley \& Sons (New York/London): 1-485.

Carozzi, A.V., 1993. Sedimentary petrography. PTR Prentice-Hall (Englewood Cliffs, NJ): 1-263.

Catt, J.A., 1986. The nature, origin and geomorphological significance of claywith-flints. In: Sieveking, G. \& Hart, M.B. (eds): The scientific study of flint and chert. Cambridge University Press (Cambridge): 151-159.

Cayeux, L., 1929. Les roches sédimentaires de France. Roches siliceuses. Mémoires pour servir à l'Explication de la Carte géologique détaillée de la France (Paris): 1-774.

Claes, S., Frederickx, E., Gullentops, F. \& Felder, W., 2001. Kaartblad (34) Tongeren. Schaal $1: 50$ 000. Toelichtingen bij de geologische kaart van België Vlaams Gewest. BGD -ANRE/ALBON 34: 1-55.

Clayton, C.J., 1986. The chemical environment of flint formation in Upper Cretaceous chalks. In: Sieveking, G. \& Hart, M.B. (eds): The scientific study of flint and chert. Cambridge University Press (Cambridge): 45-54.

Dhondt, A.V., 1979. Tenuipteria geulemensis (Mollusca: Bivalvia), An inoceramid species from the Upper Maastrichtian of the Sint Pietersberg area, the Netherlands. Annales de la Société royale de Zoologie de Belgique 108: 141-149.

Dreesen, R., Dusar, M. \& Doperé, F., 2002. Atlas Natuursteen in Limburgse monumenten. Provincie Limburg (Genk): 1-294. 
Dubelaar, C.W., Dusar, M., Dreesen, R., Felder, W.M. \& Nijland, T.G., 2006. Maastricht limestone: a regionally significant building stone in Belgium and The Netherlands. Extremely weak, yet time-resistant. In: Fort, R., Alvarez de Buergo, M., Gomez-Heras, M. \& Vazques-Calvo, C. (eds): Heritage, weathering and conservation. Taylor \& Francis Group (London): 9-14.

Dusar, M. \& Dreesen, R., 2007. Stenen uit het Mergelland. In: Nijland, T.G. (ed.): Authentiek duurzaam/Duurzaam authentiek. Proceedings $2^{\mathrm{e}}$ VlaamsNederlandse Natuursteendag, Utrecht. TN0 (Delft/Utrecht): 47-87.

Dusar, M., Dreesen, R. \& De Naeyer, A., 2009. Natuursteen in Vlaanderen, versteend verleden. Kluwer Renovatie \& Restauratie (Dordrecht): 1-562.

Dusar, M., Lagrou, D., Willems, L., Felder, P.J. \& Matthijs, J., 2005. De mergelgrotten van Hinnisdael te Vechmaal (gemeente Heers, Limburgs Haspengouw), een geologische bijdrage tot de studie van het Krijt. Geological Survey of Belgium, Professional Paper 2005/1 (301): 1-89.

Felder, P.J., 2001. Delfstoffen in Cadier en Keer. Vereniging tot Natuurbehoud Cadier en Keer (Cadier en Keer): 1-128.

Felder, P.J. \& Felder, W.M., 2008. Vergelijking van lithostratigrafie en bioklastenecozonering van de Formatie van Maastricht (laat Maastrichtien), ten westen en oosten van de Maas. Sprekende Bodem 52: 72-104.

Felder, W.M., 1975. Lithostratigrafie van het Boven-Krijt en het Dano-Montien in Zuid-Limburg en het aangrenzende gebied. In: Zagwijn, W.H. \& van Staalduinen, C.J. (eds): Toelichting bij geologische overzichtskaarten van Nederland. Rijks Geologische Dienst (Haarlem): 63-72.

Felder, W.M. \& Bosch, P.W., 1998. Geologie van de St. Pietersberg bij Maastricht. Grondboor en Hamer 52: 53-64.

Felder, W.M. \& Bosch, P.W., 2000. Geologie van Nederland, deel 5. Krijt van ZuidLimburg. TNO-NITG (Utrecht): 1-192.

Hofker, J., 1966. Maestrichtian, Danian and Paleocene Foraminifera. The Foraminifera of the type Maestrichtian in South Limburg, the Netherlands, together with the Foraminifera of the underlying Gulpen Chalk and the overlying calcareous sediments; the Foraminifera of the Dansk Chalk and the overlying Greensands and Clays as found in Denmark. Palaeontographica A, Suppl. 10: 1-376.

Indeherberge, L., Strijbos, V. \& Geussens, T., 1993. Voorkomen van het vuursteeneluvium uit het Boven-Krijt in het heuvellandschap tussen Zichen (Riemst) en Sluizen (Tongeren). LIKONA Jaarboek 1992: 7-14.

Indeherberge, L., Bogaerts, D., Geussens, T. \& Snellings, J., 1996. Tussen Vechmaal en Kanne: een geologische tocht door het Krijt van ZuidoostLimburg. LIKONA Jaarboek 1995: 7-15.

Jagt, J.W.M., 1999. Late Cretaceous-Early Palaeogene echinoderms and the K/T boundary in the southeast Netherlands and northeast Belgium - Part 1: Introduction and stratigraphy. Scripta Geologica 116: 1-57.

Jaspars, G., 1985. Groéselder Diksjenèr, Supplement. The author (Gronsveld): 1-16. Juvigné, E., 1992. Les formations cénozoiques de la carrière C.B.R. du Romont (Eben/Bassenge, Belgique). Annales de la Société géologique de Belgique 115: 159-165.

Keuller, L., 1912. Notice sur les pierres à bâtir du terrain crétacé du Limbourg belge et hollandais. Annales de la Société géologique de Belgique 39: B390-B399.

Klein, W.C., 1911. Compte rendu de l'excursion de la Société géologique de Belgique à Maestricht et à Geulem, le 11 Juin 1911. Annales de la Société géologique de Belgique 38: B237-B242.
Knauth, L.P., 1994. Petrogenesis of chert. In: Heaney, P.J., Prewitt, C.T. \& Gibbs, G.V. (eds): Silica. Physical behavior, geochemistry and materials applications. Reviews in Mineralogy 29: 233-258.

Lijdsman, P.M.E., 1944. Bouwmaterialen Natuursteen. Leerboek voor het middelbare technische onderwijs en de practijk. Stam Technische Boeken, Culemborg: 1-243.

Macar, P., 1947. Tuffeau de Maestricht. Centenaire de l'Association des Ingénieurs sortis de l'Ecole de Liège (A.I.Lg.). Congrès 1947, Section Géologie: 337-341.

Quesnel, F., 1997. Cartographie numérique en géologie de surface - Application aux altérites à silex de l'ouest du bassin de Paris. Documents du Bureau des Recherches Géologiques et Minières 263: 1-428.

Quesnel, F., Bourdillon, C. \& Laignel, B., 1996. Maastrichtien supérieur au NordOuest du Bassin de Paris (France). Témoins résiduels en Seine-Maritime. Comptes Rendus de l'Académie des Sciences de Paris, (IIa)322: 1071-1077.

Quesnel, F., Catt, J.A., Laignel, B., Bourdillon, C. \& Meyer, R., 2003. The Neogene and Quaternary Clay-with-flints north and south of the Channel: comparisons of distribution, age, genetic processes and geodynamics. Journal of Quaternary Science, Special Volume on the Quaternary of the English Channel 18(3-4): 283-294.

Slinger, A., Janse, H. \& Berends, G., 1982. Natuursteen in monumenten. Rijksdienst voor Monumentenzorg. Bosch \& Keuning (Baarn): 1-120.

Swennen, R. \& Dusar, M., 1997. Diagenesis of Late Cretaceous to Paleocene carbonates in the Rur Valley Graben (Molenbeersel borehole, NE-Belgium). Annales de la Société géologique du Nord (2)5: 215-226.

Van den Broek, J.M.M. \& Van der Waals, L., 1967. The Late Tertiary peneplain of South Limburg (The Netherlands). Geologie en Mijnbouw 45: 318-332.

Van der Ham, R., Indeherberge, L., Defour, E. \& Meuris, R., 2006. Zee-egels uit het vuursteeneluvium van Hallembaye (Montagne Saint-Pierre). Staringia 12: 1-59.

Van der Ham, R.W.J.M., Van Konijnenburg-van Cittert, J.H.A. \& Indeherberge, L., 2007. Seagrass foliage from the Maastrichtian type area (Maastrichtian, Danian, NE Belgium, SE Netherlands). Review of Palaeobotany and Palynology 144: 301-321.

Walaszczyk, I., Jagt, J.W.M. \& Keutgen, N., 2010. The youngest Maastrichtian 'true' inoceramids from the Vijlen Member (Gulpen Formation) in northeast Belgium and the Aachen area (Germany). Netherlands Journal of Geosciences 89: 147-167.

Weijnen, A.A., 1996. Etymologisch dialectwoordenboek. Van Gorcum (Assen): 1-269. 